\title{
Composition of iron oxides in Archean and Paleoproterozoic mafic-ultramafic hosted Ni-Cu-PGE deposits in northern Fennoscandia: application to mineral exploration
}

\author{
M. Moilanen ${ }^{1} \cdot$ E. Hanski ${ }^{1}$ J. Konnunaho ${ }^{2} \cdot$ T. Törmänen ${ }^{2} \cdot$ S.-H. Yang ${ }^{1} \cdot$ Y. Lahaye $^{3} \cdot$ H. O'Brien ${ }^{3} \cdot$ J. Illikainen $^{4}$
}

Received: 19 March 2019 / Accepted: 1 January 2020 / Published online: 11 January 2020

(C) The Author(s) 2020

\begin{abstract}
Using electron probe microanalyzer (EPMA) and laser ablation-inductively coupled plasma-mass spectrometry (LA-ICP-MS), we analyzed major and trace element compositions of iron oxides from Ni-Cu-PGE sulfide deposits hosted by mafic-ultramafic rocks in northern Fennoscandia, mostly focusing on Finland. The main research targets were the Archean Ruossakero Ni-(Cu) deposit; Tulppio dunite and related Ni-PGE mineralization; Hietaharju, Vaara, and Tainiovaara Ni-(Cu-PGE) deposits; and Paleoproterozoic Lomalampi PGE-(Ni-Cu) deposit. In addition, some reference samples from the Pechenga (Russia), Jinchuan (China), and Kevitsa (Finland) Ni-Cu-PGE sulfide deposits, and a barren komatiite sequence in the Kovero area (Finland) were studied. Magnetite and Crmagnetite show a wide range of trace element compositions as a result of the variation of silicate and sulfide melt compositions and their post-magmatic modification history. Most importantly, the Ni content in oxide shows a positive correlation with the Ni tenor of the sulfide phase in equilibrium with magnetite, regardless of whether the sulfide assemblage is magmatic or post-magmatic in origin. The massive sulfide samples contain an oxide phase varying in composition from $\mathrm{Cr}$-magnetite to magnetite, indicating that $\mathrm{Cr}$ magnetite can crystallize directly from sulfide liquid. The $\mathrm{Mg}$ concentration of magnetites in massive sulfide samples is lowest among the samples analyzed, and this can be regarded as a diagnostic feature of an oxide phase crystallized together with primitive Fe-rich MSS (monosulfide solid solution). Our results show that magnetite geochemistry, plotted in appropriate discrimination diagrams, together with petrographical observations could be used as an indicator of potential Ni-(Cu-PGE) mineralization.
\end{abstract}

Keywords Fe oxide $\cdot$ Magnetite $\cdot$ Trace element $\cdot$ Ni-Cu-PGE sulfide deposit $\cdot$ Fennoscandian Shield

\section{Introduction}

Orthomagmatic sulfide deposits are important sources for base- and precious metals, such as $\mathrm{Ni}, \mathrm{Cu}, \mathrm{Co}$, and PGE.

Editorial handling: P. Eilu

Electronic supplementary material The online version of this article (https://doi.org/10.1007/s00126-020-00953-1) contains supplementary material, which is available to authorized users.

M. Moilanen

marko.moilanen@oulu.fi

1 Oulu Mining School, University of Oulu, P.O. Box 3000, FI-90014 Oulu, Finland

2 Geological Survey of Finland, P.O. Box 77, FI-96101 Rovaniemi, Finland

3 Geological Survey of Finland, P.O. Box 96, FI-02151 Espoo, Finland

4 Mawson Oy, Ahjotie 7, 96320 Rovaniemi, Finland
Experimental studies and empirical observations have shown that sulfides in these deposits are products of segregation of an immiscible sulfide liquid from a silicate liquid (e.g., Naldrett 2004; Fonseca et al. 2008). The sulfide liquid sequesters chalcophile metals from its parental silicate melt, which may lead to the formation of an economically viable ore deposit (e.g., Naldrett 2004; Fonseca et al. 2008). The sulfide mineral assemblage in these deposits typically consists of pyrrhotite, pentlandite, chalcopyrite, and pyrite (Naldrett 2004). These sulfides are commonly associated with iron oxides (e.g., magnetite and Cr-magnetite) because of the capability of sulfide liquid to dissolve significant amounts of oxygen, leading to the crystallization of magnetite together with early-forming Fe-rich monosulfide solid solution (MSS) and later, at lower temperatures, $\mathrm{Cu}$-rich intermediate solid solution (ISS) (e.g., Naldrett 2004; Dare et al. 2012). The amount of dissolved oxygen in a sulfide melt is dependent on the conditions and metal contents of the sulfide liquid. Experimental studies have demonstrated that the solubility of oxygen increases with 
increasing oxygen fugacity and iron content and decreases with increasing nickel $(\mathrm{Ni})$ and copper $(\mathrm{Cu})$ contents, with the role of Ni being more important than that of $\mathrm{Cu}$ in reducing the oxygen solubility of the system (e.g., Lee 1999; Fonseca et al. 2008).

In mafic and ultramafic magma and related sulfide systems, spinels show wide ranges in composition that are controlled by several factors (parental magma composition, mineral assemblages, degree of fractionation of sulfide liquid, temperature, and oxygen fugacity). The parental magmas differ in their degree of differentiation and compatible and incompatible trace element contents, which are reflected in the concentrations of, for example, $\mathrm{Cr}, \mathrm{Ti}, \mathrm{Nb}, \mathrm{Al}$, and $\mathrm{V}$ in the spinel phase they crystallize (e.g., Barnes and Roeder 2001; Boutroy et al. 2014).

Due to the high $\mathrm{Cr}$ contents of komatiitic magmas, the first oxide to crystallize from related sulfide liquids can be expected to be chrome-bearing spinel. Fonseca et al. (2008) concluded that most massive sulfide liquids behave as open systems in relation to their oxygen content and suggested that the diffusion of oxygen out of sulfide liquid can lead to precipitation of magnetite and/or chromite/Cr-magnetite (Cr-spinel) near or at the boundary between sulfide liquid and silicate liquid. Frost and Groves (1989) observed exactly this type of boundary in the Kambalda Ni sulfide ores (Australia) where Cr-bearing magnetite had formed near the magmatic contact between sulfides and their komatiite host rock. Ewers et al. (1976) concluded that Cr-bearing spinel in Kambalda massive sulfides were crystallized directly from the sulfide liquid. Based on these observations, it is apparent that chromite, Cr-magnetite, and magnetite can crystallize as primary minerals from sulfide liquids in mafic-ultramafic systems.

An additional factor that affects the iron oxide content of $\mathrm{Ni}-\mathrm{Cu}$-PGE sulfide ores is the degree of post-magmatic hydrothermal oxidation. There are examples where the bulk of the magmatic sulfide mineral assemblage has been altered to secondary magnetite replacing sulfides and Ni-rich sulfide minerals, such as millerite and violarite (e.g., the Vaara Ni$\mathrm{Cu}-\mathrm{PGE}$ deposit, Konnunaho et al. 2013; the Jinchuan Ni-Cu deposit, Yang et al. 2018).

The abundance and composition of oxide phases in magmatic Ni-Cu-PGE sulfide deposits have attracted much attention in recent years due to the advent of new accurate analytical tools for in-situ trace element analysis, especially laser ablation-inductively coupled plasma-mass spectrometry (LA-ICP-MS) (e.g., Dupuis and Beaudoin 2011; Dare et al. 2012, 2014; Boutroy et al. 2014). For example, the study of the Sudbury ore deposits by Dare et al. (2012) showed that all lithophile elements (Cr, Ti, V, Al, Mn, Sc, Nb, Ga, Ge, Ta, Hf, $\mathrm{W}$, and $\mathrm{Zr}$ ) are compatible into $\mathrm{Fe}$ oxide crystallized from sulfide liquid. The concentrations of these elements vary as a function of the fractionation of the sulfide melt (MSS to ISS), thus providing evidence that $\mathrm{Fe}$ oxide geochemistry can be a sensitive indicator for the degree of fractionation of the sulfide liquid system. Dupuis and Beaudoin (2011) identified differences in the composition of magnetite between $\mathrm{Ni}$ $\mathrm{Cu}-\mathrm{PGE}$ sulfide deposits and hydrothermal and sedimentary deposits. Magnetite in Ni-Cu-PGE sulfide deposits is characterized by relatively high $\mathrm{Ni}$ and $\mathrm{Cr}$ contents. Ward et al. (2018) introduced a discrimination diagram to distinguish magnetites from mineralized and barren mafic-ultramafic systems. Nadoll et al. (2014) studied the composition of magnetite from various types of hydrothermal ore deposits and proposed several discrimination diagrams and elemental concentration boundaries to discriminate between hydrothermal magnetite and igneous magnetite.

In this study, we used laser ablation-inductively coupled plasma-mass spectrometry (LA-ICP-MS) and electron probe microanalyzer (EPMA) to study magnetite and $\mathrm{Cr}$-magnetite compositions ( $\mathrm{Cr}$ content of $>1 \mathrm{wt} . \%$ ) in different types of $\mathrm{Ni}-\mathrm{Cu}-\mathrm{PGE}$ deposits in Finland (Fig. 1). The following Archean deposits were studied: the Ruossakero Ni- $(\mathrm{Cu})$ deposit, the Tulppio dunite and related low-grade Ni-PGE mineralization, and the Hietaharju, Vaara and Tainiovaara Ni-(Cu-PGE) deposits. The komatiite-hosted Lomalampi PGE-(Ni-Cu) deposit represents the Paleoproterozoic deposits. In addition, some reference samples from the $1.98 \mathrm{Ga}$ Pechenga (Russia), $\sim 0.83$ Ga Jinchuan (China) and 2.06 Ga Kevitsa (northern Finland) deposits, and a barren Archean komatiite sequence in the Kovero area (eastern Finland) were studied. The studied deposits have various magmatic and post-magmatic histories, providing a good opportunity to investigate the characteristics and composition of oxide phases formed under different geological conditions and from different parental magma compositions.

\section{Geological background}

The locations of the main research targets are shown in Fig. 1, and a summary of the information of the deposits is presented in Table 1.

\section{Ruossakero Ni-(Cu) deposit}

The Archean komatiite-hosted Ruossakero Ni- $(\mathrm{Cu})$ sulfide deposit is located in a greenstone belt of the Rommaeno complex in the northwest part of Finland (Fig. 1). The lowermost unit in the belt consists of mafic-ultramafic volcanic rocks, including komatiitic olivine cumulates and noncumulate rocks and minor ca. 2.93 Ga sulfide-bearing felsic volcanic rocks, and interlayers of banded iron formation (Karinen et al. 2015; Konnunaho et al. 2015; DigiKP 2018). The rocks were metamorphosed under amphibolite facies conditions (Metamorphism of Finland 2018), and the primary silicate minerals have been replaced by secondary 
Fig. 1 Locations of the studied komatiite-hosted sulfide deposits and the Kevitsa Ni-CuPGE deposit in Finland on simplified geological map. Modified after Konnunaho et al. (2015), Konnunaho et al. (2016), Luukas et al. (2017) and DigiKp (2018)

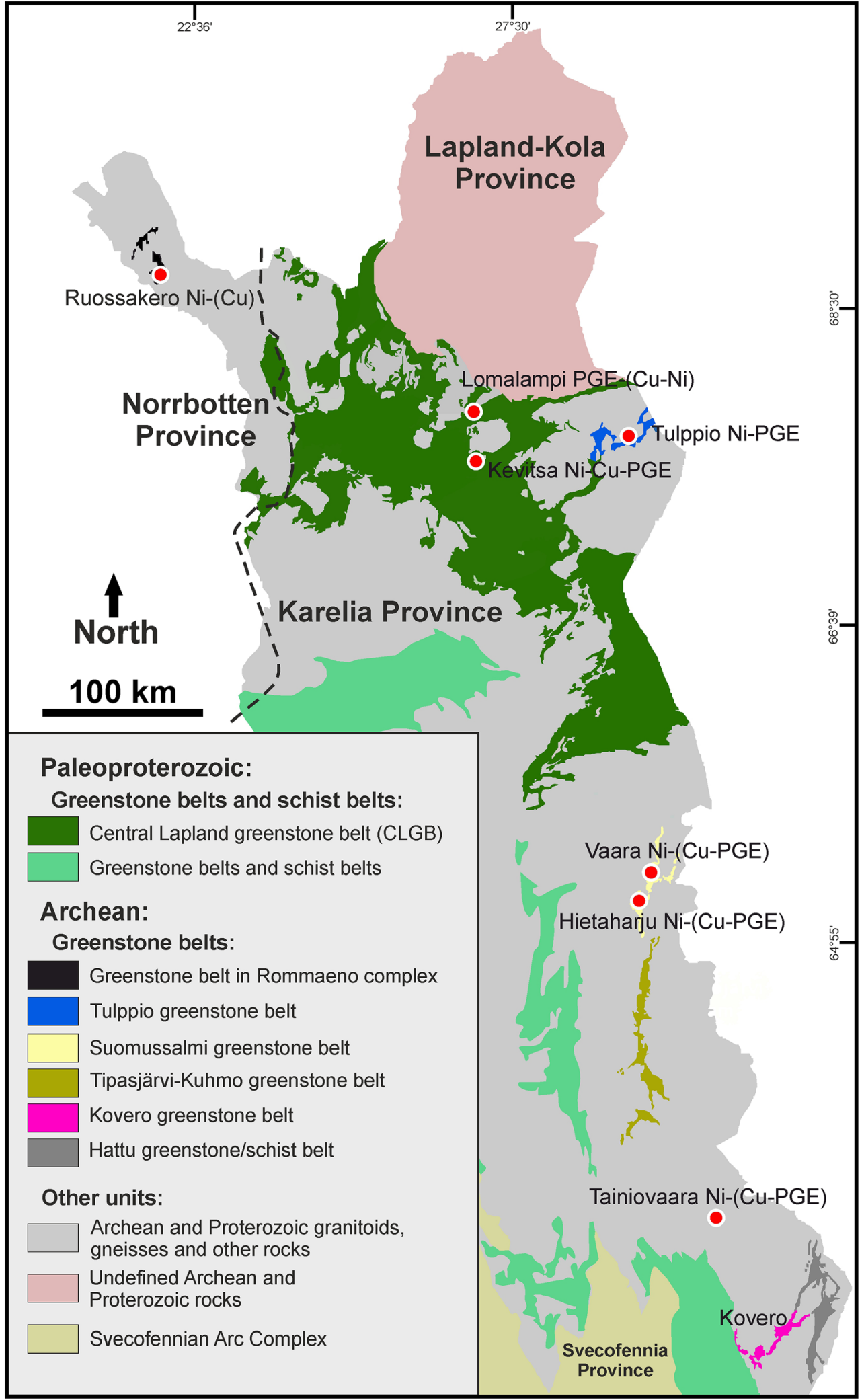

metamorphic minerals. The common silicate minerals in the komatiitic non-cumulate rocks are amphiboles, chlorite, serpentine, talc, and olivine (Konnunaho et al. 2015). The Ruossakero komatiitic olivine cumulate body is the largest 
Table 1 Summary information of the studied Ni-Cu-PGE deposits

\begin{tabular}{|c|c|c|c|c|c|c|}
\hline Deposit & Location & Age & Parental magma & $\begin{array}{l}\text { Host rock of } \\
\text { mineralization }\end{array}$ & Magnetite occurrence style & References \\
\hline $\begin{array}{l}\text { Ruossakero } \\
\text { Ni- }(\mathrm{Cu})\end{array}$ & $\begin{array}{l}\text { Enontekiö, } \\
\text { northern } \\
\text { Finland }\end{array}$ & Archean & $\begin{array}{l}\text { Komatiite } \\
\quad \text { (Ti-depleted) }\end{array}$ & $\begin{array}{l}\text { Olivine } \\
\text { cumulate }\end{array}$ & $\begin{array}{l}\text { Disseminated magnetite with } \\
\text { disseminated sulfides and } \\
\text { remobilized Cr-magnetite veins } \\
\text { with Ni sulfides. Magnetite rims } \\
\text { in chromite grains. }\end{array}$ & $\begin{array}{l}\text { Konnunaho et al. } \\
\text { (2015), } \\
\text { Konnunaho et al. } \\
\text { (2016) }\end{array}$ \\
\hline $\begin{array}{l}\text { Tulppio Ni-PGE } \\
\text { mineralization }\end{array}$ & $\begin{array}{l}\text { Savukoski, } \\
\text { northern } \\
\text { Finland }\end{array}$ & Archean & $\begin{array}{l}\text { Komatiite or } \\
\text { komatiitic basalt }\end{array}$ & Dunite & $\begin{array}{l}\text { Cr-magnetite grains and } \\
\text { Cr-magnetite and magnetite } \\
\text { grains with trace sulfides. }\end{array}$ & $\begin{array}{l}\text { Heikura et al. (2009) } \\
\text { and Maier et al. } \\
\text { (2013) }\end{array}$ \\
\hline $\begin{array}{l}\text { Vaara } \\
\quad \text { Ni-(Cu-PGE) }\end{array}$ & $\begin{array}{l}\text { Kuhmo, } \\
\text { eastern } \\
\text { Finland }\end{array}$ & Archean & $\begin{array}{l}\text { Komatiite } \\
\quad \text { (Al-undepleted) }\end{array}$ & $\begin{array}{l}\text { Olivine } \\
\text { cumulate }\end{array}$ & $\begin{array}{l}\text { Sulfide-magnetite aggregates } \\
\text { (oxidation of sulfides), } \\
\text { interstitial magnetite (from } \\
\text { serpentinization of silicates), } \\
\text { magnetite veins and secondary } \\
\text { magnetite rims around chromite } \\
\text { grains. }\end{array}$ & $\begin{array}{l}\text { Konnunaho et al. } \\
\text { (2013), } \\
\text { Konnunaho et al. } \\
\text { (2015) and } \\
\text { Konnunaho et al. } \\
\text { (2016) }\end{array}$ \\
\hline $\begin{array}{l}\text { Hietaharju } \\
\text { Ni-(Cu-PGE) }\end{array}$ & $\begin{array}{l}\text { Kuhmo, } \\
\text { eastern } \\
\text { Finland }\end{array}$ & Archean & Komatiitic basalt & $\begin{array}{l}\text { Olivine } \\
\text { cumulate }\end{array}$ & $\begin{array}{l}\text { Magnetite and Cr-magnetite in } \\
\text { massive sulfides, Cr-magnetite } \\
\text { with sheared and disseminated } \\
\text { sulfides and magnetite rims } \\
\text { around chromite grains. }\end{array}$ & $\begin{array}{l}\text { Konnunaho et al. } \\
\text { (2015), } \\
\text { Konnunaho et al. } \\
\text { (2016) and } \\
\text { Konnunaho et al. } \\
\text { (2016) }\end{array}$ \\
\hline $\begin{array}{l}\text { Tainiovaara } \\
\text { Ni-(Cu-PGE) }\end{array}$ & $\begin{array}{l}\text { Lieksa, } \\
\text { eastern } \\
\text { Finland }\end{array}$ & Archean & $\begin{array}{l}\text { Komatiite } \\
\quad \text { (Al-undepleted) }\end{array}$ & $\begin{array}{l}\text { Olivine } \\
\text { cumulate }\end{array}$ & $\begin{array}{l}\text { Magnetite and Cr-magnetite with } \\
\text { disseminated sulfides. Magnetite } \\
\text { rims around chromite grains. }\end{array}$ & $\begin{array}{l}\text { Konnunaho et al. } \\
\text { (2015) and } \\
\text { Konnunaho et al. } \\
\text { (2016) }\end{array}$ \\
\hline Kovero & $\begin{array}{l}\text { Eastern } \\
\text { Finland }\end{array}$ & Archean & Komatiite & $\begin{array}{l}\text { Olivine } \\
\text { cumulates } \\
\text { with no } \\
\text { known } \\
\text { mineralization }\end{array}$ & $\begin{array}{l}\text { Disseminated magnetite, } \\
\text { Cr-magnetites after alteration of } \\
\text { chromite. }\end{array}$ & Konnunaho (1999) \\
\hline $\begin{array}{l}\text { Lomalampi } \\
\text { PGE-(Ni-Cu) }\end{array}$ & $\begin{array}{l}\text { Sodankylä, } \\
\text { northern } \\
\text { Finland }\end{array}$ & Paleoproterozoic & $\begin{array}{l}\text { Komatiitic } \\
\text { basalt-low-Mg } \\
\text { komatiite } \\
\text { (Al-undepleted) }\end{array}$ & $\begin{array}{l}\text { Olivine } \\
\text { cumulate }\end{array}$ & $\begin{array}{l}\text { Magnetite and Cr-magnetite with } \\
\text { sulfides, dissemination, } \\
\text { remobilized magnetite veins and } \\
\text { magnetite rims around chro- } \\
\text { mites. }\end{array}$ & $\begin{array}{l}\text { Konnunaho et al. } \\
\text { (2015), } \\
\text { Konnunaho et al. } \\
\text { (2016) and } \\
\text { Törmänen et al. } \\
\text { (2016) }\end{array}$ \\
\hline $\begin{array}{l}\text { Kevitsa } \\
\quad \text { Ni-Cu-PGE }\end{array}$ & $\begin{array}{l}\text { Sodankylä, } \\
\text { northern } \\
\text { Finland }\end{array}$ & Paleoproterozoic & Picrite-basalt & $\begin{array}{l}\text { Olivine } \\
\text { pyroxenite }\end{array}$ & $\begin{array}{l}\text { Magnetite and Cr-magnetite with } \\
\text { disseminated sulfides. }\end{array}$ & $\begin{array}{l}\text { Mutanen (1997), } \\
\text { Yang et al. } \\
\text { (2013), } \\
\text { Santaguida et al. } \\
\text { (2015) and } \\
\text { Luolavirta et al. } \\
\text { (2017) }\end{array}$ \\
\hline $\begin{array}{l}\text { Pechenga } \\
\text { Ni-Cu-PGE }\end{array}$ & $\begin{array}{l}\text { Northwest } \\
\text { Russia }\end{array}$ & Paleoproterozoic & Ferropicrite & Gabbro-wehrlite & $\begin{array}{l}\text { Magnetite and Cr-magnetite in } \\
\text { massive sulfides and dissemi- } \\
\text { nated magnetite and sulfide. }\end{array}$ & $\begin{array}{l}\text { Hanski (1992) and } \\
\text { Hanski et al. } \\
\text { (2011) }\end{array}$ \\
\hline $\begin{array}{l}\text { Jinchuan } \\
\quad \text { Ni-Cu-PGE }\end{array}$ & $\begin{array}{l}\text { Northwest } \\
\text { China }\end{array}$ & Proterozoic & High-Mg basalt & Dunite-lherzolite & $\begin{array}{l}\text { Magnetite with remobilized and } \\
\text { sheared textured disseminated } \\
\text { sulfides. }\end{array}$ & $\begin{array}{l}\text { Chai and Naldrett } \\
\text { (1992) and Yang } \\
\text { et al. (2018) }\end{array}$ \\
\hline
\end{tabular}

ultramafic body in the NW Lapland, Finland, and hosts a disseminated $\mathrm{Ni}-(\mathrm{Cu})$ sulfide mineralization (Konnunaho et al. 2015). Disseminated sulfides occur mostly in the central and upper parts of the olivine cumulate body. The sulfide assemblage is dominated by pyrite and millerite
( \pm violarite) with small amounts of chalcopyrite, pentlandite, and pyrrhotite, indicating that the primary magmatic sulfides (pyrrhotite-pentlandite-chalcopyrite assemblages) have been oxidized by low-temperature hydrothermal processes (Konnunaho et al. 2015). 


\section{Vaara and Hietaharju Ni-(Cu-PGE) deposits}

The Vaara and Hietaharju komatiite-hosted sulfide deposits are located in the Archean Suomussalmi greenstone belt in eastern Finland (Fig. 1). The rock types in the Vaara area consist of ultramafic rocks, phyllites, black schists and sulfide-bearing sericite schists, and tholeiitic basalts. The area is deformed and folded, and felsic volcanic rocks are intervened by cumulate rocks (Luukkonen et al. 2002; Papunen et al. 2009).

In the surface projection, the Vaara ultramafic lens is approximately $1 \mathrm{~km}$ long and $400 \mathrm{~m}$ wide (Konnunaho et al. 2013; Konnunaho et al. 2015). The disseminated sulfide mineralization is hosted by metamorphosed Cr-poor komatiitic olivine mesocumulates (Konnunaho 2016). The deposit contains three separate mineralized sulfide zones (Konnunaho et al. 2015), which vary in thickness from a couple of meters (at the northernmost end) up to $\sim 50 \mathrm{~m}$ (at the southernmost end). The sulfide assemblage consists of pyrite, millerite, violarite, pentlandite, and a minor amount of chalcopyrite. Interstitial sulfides have been extensively replaced by secondary magnetite. The occurrence of abundant secondary magnetite, Ni-rich sulfides (millerite and violarite), and pyrite and the lack of pyrrhotite indicate operation of low-temperature hydrothermal oxidation processes with a significant loss of sulfur, leading to major upgrading of the original metal tenors of the Vaara deposit (Konnunaho et al. 2013).

The Hietaharju deposit is located $18 \mathrm{~km}$ southwest of the Vaara deposit. It is hosted by metamorphosed olivine-pyroxene cumulates of komatiitic basalts, which are surrounded by sedimentary schists. The following lithological units occur in the Hietaharju area: felsic to mafic metavolcanic rocks, komatiitic basalts, and sulfide-bearing metasedimentary rocks, such as phyllites and black schists (Konnunaho et al. 2016). The Hietaharju Ni-(Cu-PGE) deposit is mainly composed of disseminated sulfides with some massive to semi-massive veins and breccia-textured sulfides (Konnunaho et al. 2016) occur also. The host cumulate is $\sim 100 \mathrm{~m}$ thick and $\sim 1 \mathrm{~km}$ long and its mineralized part is $\sim 200 \mathrm{~m}$ long along strike and $\sim 50 \mathrm{~m}$ wide, extending to a depth of at least $200 \mathrm{~m}$ (Konnunaho et al. 2016). Pyrrhotite, pentlandite, and chalcopyrite are the most common sulfide minerals at Hietaharju.

\section{Tainiovaara Ni-(Cu-PGE) deposit}

The Tainiovaara deposit is hosted by a komatiitic olivine cumulate body located in one small greenstone belt relicts in the Archean Lieksa complex, eastern Finland (Fig. 1). It is about $\sim 180 \mathrm{~m}$ long and $\sim 80 \mathrm{~m}$ wide and hosts a Ni-(Cu-PGE) deposit, which was mined in the 1980s (Pekkarinen 1980; Vanne 1981; Konnunaho et al. 2015). It consists of disseminated sulfides in the metamorphosed, totally serpentinized olivine cumulate body. There is also some small massive to semi-massive and net-textured sulfide accumulations occurring in the bottom part of the Cr-poor olivine cumulate body (Vanne 1981; Papunen 1989; Konnunaho et al. 2015). The major sulfide minerals are pyrrhotite and pentlandite with minor chalcopyrite and pyrite, representing a moderately modified magmatic sulfide assemblage. The Tainiovaara deposit is moderately enriched in $\mathrm{Cu}$ and PGE, but not as significantly as in some other Finnish PGE-enriched komatiitic deposits (e.g., Lomalampi, Vaara and Hietaharju), (Konnunaho et al. 2015; Konnunaho 2016).

\section{Tulppio Ni-PGE mineralization}

The Archean komatiitic Tulppio dunite body is located in eastern Lapland (Fig. 1) in the Tulppio greenstone belt composed of felsic to ultramafic (komatiitic) volcanic rocks and associated mica schists and gneisses (Juopperi and Vaasjoki 2001; Sorjonen-Ward and Luukkonen 2005). The Tulppio dunite has an approximate surface extension of $1.5 \times 4.5 \mathrm{~km}$ and is composed of medium-grained olivine adcumulates to mesocumulates, with minor peridotitic to gabbroic cumulates at the contacts of the body. Olivine is well-preserved in the central part of the body, being more altered towards its edges. Based on the maximum forsterite content of olivine, Fo 91, the Tulppio dunite was formed from a low-Mg komatiitic parental magma. Exploration drilling has revealed a weak sulfide-mineralized zone in the middle part of the dunite body (Heikura et al. 2009) with a sulfide mineral assemblage consisting mainly of pyrrhotite and pentlandite.

\section{Lomalampi PGE-(Ni-Cu) deposit}

The komatiite-hosted Lomalampi PGE-(Ni-Cu) deposit is situated in the Central Lapland greenstone belt (CLGB; Fig. 1) in northern Finland. The CLGB is composed of sedimentaryvolcanic rocks, which were formed during rifting of the Archean craton. The deposition of these Karelian supracrustal rocks took place in intracratonic and cratonic margin settings between ca. $2.5 \mathrm{Ga}$ and $2.0 \mathrm{Ga}$. Multiple metamorphic and tectonic events related to the Svecofennian orogeny (1.91$1.80 \mathrm{Ga}$ ) have affected the CLGB (e.g., Lehtonen et al. 1998; Hanski and Huhma 2005; Lahtinen et al. 2005). The Savukoski Group in the upper part of the stratigraphy is characterized by pelitic metasediments and abundant komatiitic and picritic volcanism (Hanski and Huhma 2005) and hosts the Lomalampi and Kevitsa Ni-Cu-PGE sulfide deposits. The Kevitsa intrusion has a U-Pb zircon age of $2058 \pm 4 \mathrm{Ma}$ (Mutanen and Huhma 2001), and the komatiites of the Savukoski Group have a Sm-Nd age of $2056 \pm 25 \mathrm{Ma}$ (Hanski et al. 2001), which is consistent with the Re-Os age of $2058 \pm 93$ Ma obtained for the Lomalampi olivine cumulate body by Moilanen et al. (2019). 
The Lomalampi area is composed mostly of komatiites and komatiitic basalts. They were metamorphosed under greenschist to lower amphibolite facies conditions, resulting in a mineral assemblage of serpentine-chlorite-talc \pm amphibole in ultramafic rocks. Komatiitic rocks occur as volcanoclastic rock units, thin flow facies units, and several olivine \pm pyroxene cumulate bodies. One of these bodies is $\sim 30$ to $\sim 65 \mathrm{~m}$ thick and $\sim 700 \mathrm{~m}$ long and hosts the Lomalampi PGE-(Ni-Cu) mineralization. It represents either a subvolcanic sill or a cumulate part of a thick lava flow. The sulfide mineralization is of lowgrade disseminated type and forms a zone varying from a few $\mathrm{m}$ up to $\sim 40 \mathrm{~m}$ in thickness (Törmänen et al. 2016). The main sulfide is pyrrhotite with subordinate amounts of pentlandite and chalcopyrite and trace amounts of sulf-arsenides and diarsenides. Compared to other occurrences of komatiitic Ni$\mathrm{Cu}-\mathrm{PGE}$ mineralization in Finland, the Lomalampi deposit has a low Ni content $(\sim 0.1$ to $\sim 0.3 \mathrm{wt} . \%)$, slightly elevated $\mathrm{Cu}(\sim 0.05$ to $\sim 0.1$ wt. $\%)$, and relatively high PGE concentrations (up to $\sim 2 \mathrm{ppm}$ ). The $\mathrm{Pt} / \mathrm{Pd}$ ratio is high, averaging $\sim 2.2$, as opposed to $\sim 0.5$ in other Finnish komatiite-hosted Ni-CuPGE deposits, being also unique among komatiite-hosted sulfide deposits globally (Konnunaho et al. 2015; Törmänen et al. 2016).

\section{Kovero komatiites}

The Kovero komatiites occur in the Archean Kovero greenstone belt (Fig. 1) in eastern Finland (Konnunaho 1999; Huhma et al. 2012). These komatiites (olivine cumulates and non-cumulate rocks) occur as lenses within association with tholeiitic volcanic rocks. The komatiitic olivine cumulates at Kovero are highly altered serpentinites and talc-serpentine rocks. To date, no Ni-Cu-PGE mineralization is known to exist in the area.

\section{Samples and iron oxide petrography}

Samples were collected from drill cores at the national drill core archive of the Geological Survey of Finland. Also, samples from previous studies and some reference samples from the rock collection of Oulu Mining School, University of Oulu, were used. From each deposit, one to seven polished thin sections or thick sections $(\sim 100 \mu \mathrm{m})$ were prepared for in-situ microprobe or LA-ICP-MS analysis.

Samples from the Ruossakero deposit contain disseminated sulfides (dominated by pyrite and millerite and variable amounts of pyrrhotite, pentlandite and chalcopyrite) with disseminated subhedral-anhedral magnetite and Cr-magnetite, which occur as sulfide-oxide aggregates (Fig. 2e) and individual oxide grains with various sizes $(\sim 10-200 \mu \mathrm{m})$. Oxides also show other modes of occurrence, including remobilized Cr-magnetite veins with $\mathrm{Ni}$ sulfides, altered chromite grains with magnetite rims, and mobilized later-stage magnetite veins. We also found small inclusions of millerite and pentlandite-pyrrhotite in Cr-bearing magnetite grains from the Ruossakero deposit.

The samples from the Vaara deposit contain disseminated sulfides as interstitial blebs of sulfide-magnetite aggregates between serpentine pseudomorphs after cumulus olivine (Figs. 2c and 4b). Magnetite forms mostly anhedral crystals in these mineral aggregates. The sulfides are dominated by pyrite and millerite with minor violarite. Magnetite also forms rims around altered chromite grains. Secondary magnetite after serpentinization of olivine, mobilized later-stage magnetite-sulfide veins, and some ilmenite also occur. The Vaara deposit is a special case as a substantial amount of magnetite has been generated via post-magmatic oxidation of sulfide minerals (Konnunaho et al. 2013) (Figs. 2c and 4b).

The samples from the Hietaharju deposit represent both massive and disseminated mineralization. Massive sulfide samples contain euhedral to rounded, subhedral magnetite grains (Fig. 2a) (diameter $\sim 100-500 \mu \mathrm{m}$ ) imbedded in a sulfide mass consisting of pyrrhotite, pentlandite, and chalcopyrite with a very small amount of silicates, whereas in slightly less massive sulfide samples with streaks or blebs of silicates, some Cr-magnetite occurs in association with silicates. Disseminated sulfide samples (pyrrhotite, pentlandite, and chalcopyrite) do not appear to contain magnetite but rather subhedral to anhedral Cr-magnetite varying from $\sim 10$ to $100 \mu \mathrm{m}$ in diameter (Fig. 2b). Figure 2b shows an example of a sheared pyrrhotite-pentlandite-chalcopyrite assemblage together with Cr-magnetite. In these samples, most of the oxides are $\mathrm{Cr}$-magnetites, which have a dark core and magnetite rim and most likely were chromites originally. The same samples also have homogenous Cr-magnetite grains with no magnetite rims. In the Hietaharju samples (Fig. 4a), we observed rounded pentlandite-pyrrhotite and chalcopyrite inclusions ( $\sim 5$ to $100 \mu \mathrm{m}$ diameter) in magnetite and also recognized tiny $(\sim 1-2 \mu \mathrm{m}$ diameter $)$ platinum-group mineral (PGM) inclusions (Pt-As phase).

From the Tainiovaara deposit, we studied disseminated sulfide samples with pyrrhotite and pentlandite and some chalcopyrite. They contain subhedral-anhedral Cr-magnetite and some magnetite (diameter $\sim 50-500 \mu \mathrm{m}$ ), which occur as sulfide-oxide grain aggregates and also as individual grains. Figure $2 \mathrm{~d}$ shows an example of sheared disseminated sulfides with magnetite grains. Magnetite also occurs around altered chromite grains. Tainiovaara magnetites could have been originally chromites, which are altered to magnetite, because some grains still exhibit a zoned texture with a slightly darker chromium-bearing core (see Fig. $3 \mathrm{e}$ in Moilanen et al. 2019). Nickel sulfide and pyrite inclusions were observed in magnetite in the samples from Tainiovaara.

From the Lomalampi deposit, we studied samples with weak sulfide dissemination. Oxides are present as euhedral- 
Fig. 2 Photomicrographs (a-d) and back-scattered electron images ( $\mathrm{E}$ and $\mathrm{F}$ ) of magnetites from the studied Ni-Cu-PGE deposits. a Hietaharju massive sulfides with euhedral equidimensional magnetite grains. b Hietaharju disseminated and sheared sulfides with magnetite and $\mathrm{Cr}$-magnetite. c Vaara disseminated sulfides, magnetite-sulfide aggregate. Magnetite is replacing sulfides. d Tainiovaara disseminated sulfides with Cr-magnetite and magnetite. e Ruossakero disseminated and remobilized sulfides with zoned Cr-magnetite. f Lomalampi disseminated sulfides with magnetite. $\mathrm{CPY}=$ chalcopyrite, $\mathrm{Cr}-$ MGT $=$ Cr-magnetite, $\mathrm{MGT}=$ magnetite, $\mathrm{MIL}=$ millerite, $\mathrm{PN}=$ pentlandite, $\mathrm{PO}=$ pyrrhotite, $\mathrm{PY}=$ pyrite, $\mathrm{VIOL}=$ violarite
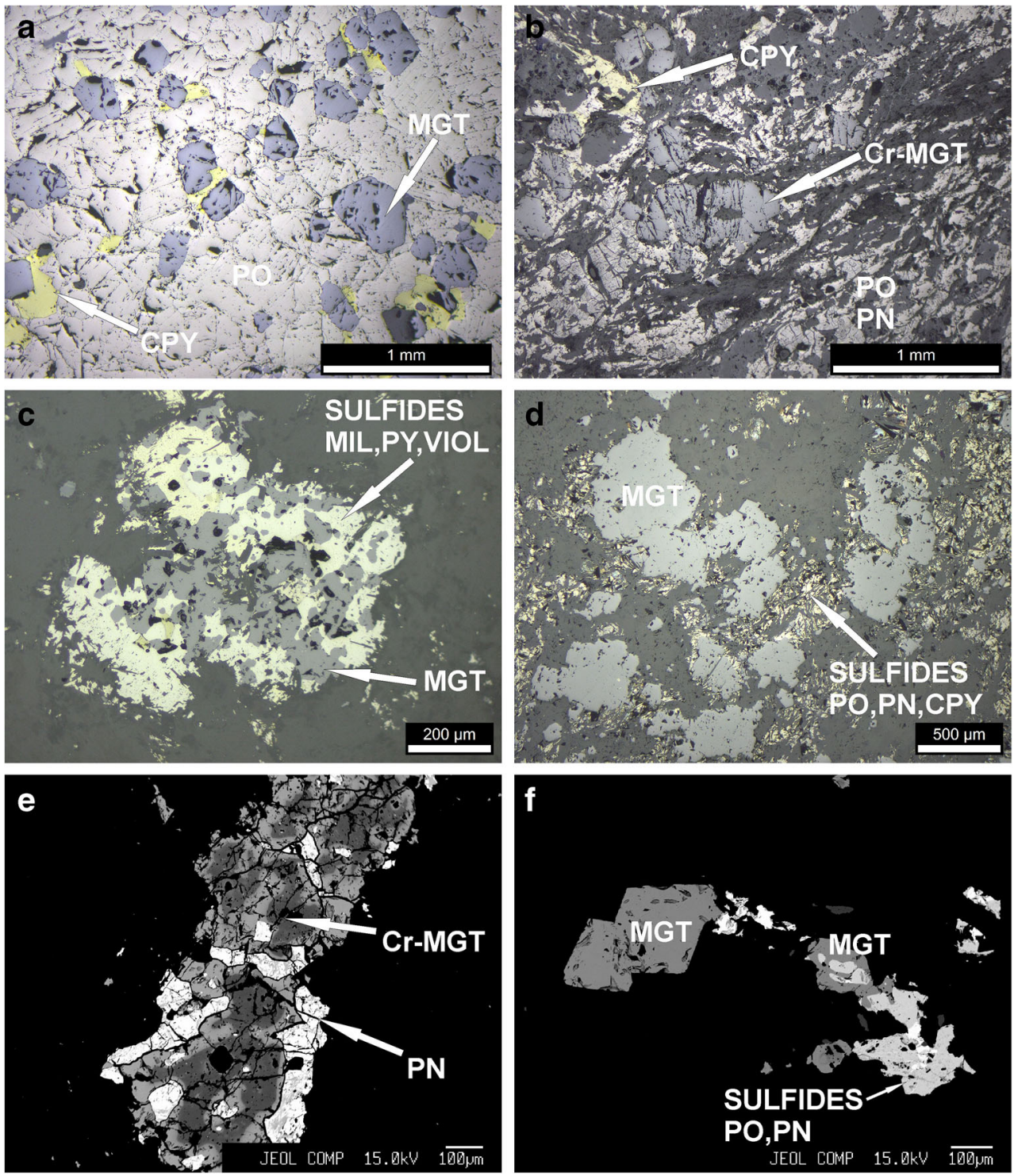

subhedral magnetite (diameter $\sim 50-200 \mu \mathrm{m}$ ), Cr-magnetite, remobilized magnetite veins, and trace amounts of ilmenite. As illustrated in Fig. 2f, magnetite occurs together with sulfides (pyrrhotite, pentlandite, and chalcopyrite) as sulfidemagnetite aggregates and also as individual euhedral grains. In addition, some remobilized magnetite-sulfide veins and magnetite rims around altered chromite grains occur. There are rounded pentlandite-pyrrhotite inclusions inside magnetite (Fig. 4c).

The samples from the Tulppio mineralization contain trace sulfides with individual subhedral-euhedral $\mathrm{Cr}$-magnetite (Fig. 3a) and magnetite (diameter $\sim 50-500 \mu \mathrm{m}$ ) grains. A minor amount of magnetite occurs together with sulfides (pyrrhotite and pentlandite). Magnetite also occurs as rims around altered chromite grains. Remobilized, vein-hosted Cr-rich magnetites and magnetites have rounded pyrrhotitepentlandite inclusions (Fig. 4d).
The samples from the Kovero komatiites contain disseminated subhedral to anhedral magnetite grains (diameter $\sim 50$ $500 \mu \mathrm{m}$ ) in a chlorite schist (Fig. 3f), representing a metamorphic oxide phase, and Cr-magnetite after extensive alteration of chromite in a serpentine-amphibole rock with a preserved cumulate texture. The samples have only trace amounts of sulfides and some ilmenite.

Some reference samples from the Pechenga and Kevitsa $\mathrm{Ni}$-Cu-PGE deposits were also studied. Of the four samples from Pechenga, two represent massive sulfide ore from the basal part of the Pilgujärvi intrusion (Fig. 3d), containing subhedral-anhedral magnetite grains (diameter $\sim 50$ $200 \mu \mathrm{m}$ ) in massive sulfides with small amounts of sulfide inclusions (Fig. 4e, f). The other two samples are from the Kammikivi sill (Hanski et al. 2011) and represent, respectively, an altered olivine cumulate with disseminated sulfides and magnetite and a relatively unaltered olivine cumulate with $\mathrm{Cr}$ - 
Fig. 3 Back-scattered electron images $(\mathbf{a}-\mathbf{e})$ and photomicrograph (f) of magnetites from the studied $\mathrm{Ni}$ $\mathrm{Cu}$-PGE deposits. a Cr-magnetite from Tulppio low-grade disseminated sulfides. b Kevitsa disseminated Normal Ore sample with sulfides and magnetite. c Kevitsa disseminated Ni-PGE sulfide sample with sulfides and magnetite. d Pechenga massive sulfides with rounded magnetite grains. e Jinchuan remobilized sulfides with magnetite and $\mathrm{Cr}$-magnetite. f Barren Kovero sample with magnetite grains. $\mathrm{CPY}=$ chalcopyrite, $\mathrm{Cr}-\mathrm{MGT}=\mathrm{Cr}-\mathrm{magnetite}$, $\mathrm{MGT}=$ magnetite, $\mathrm{PN}=$ pent landite, $\mathrm{PO}=$ pyrrhotite
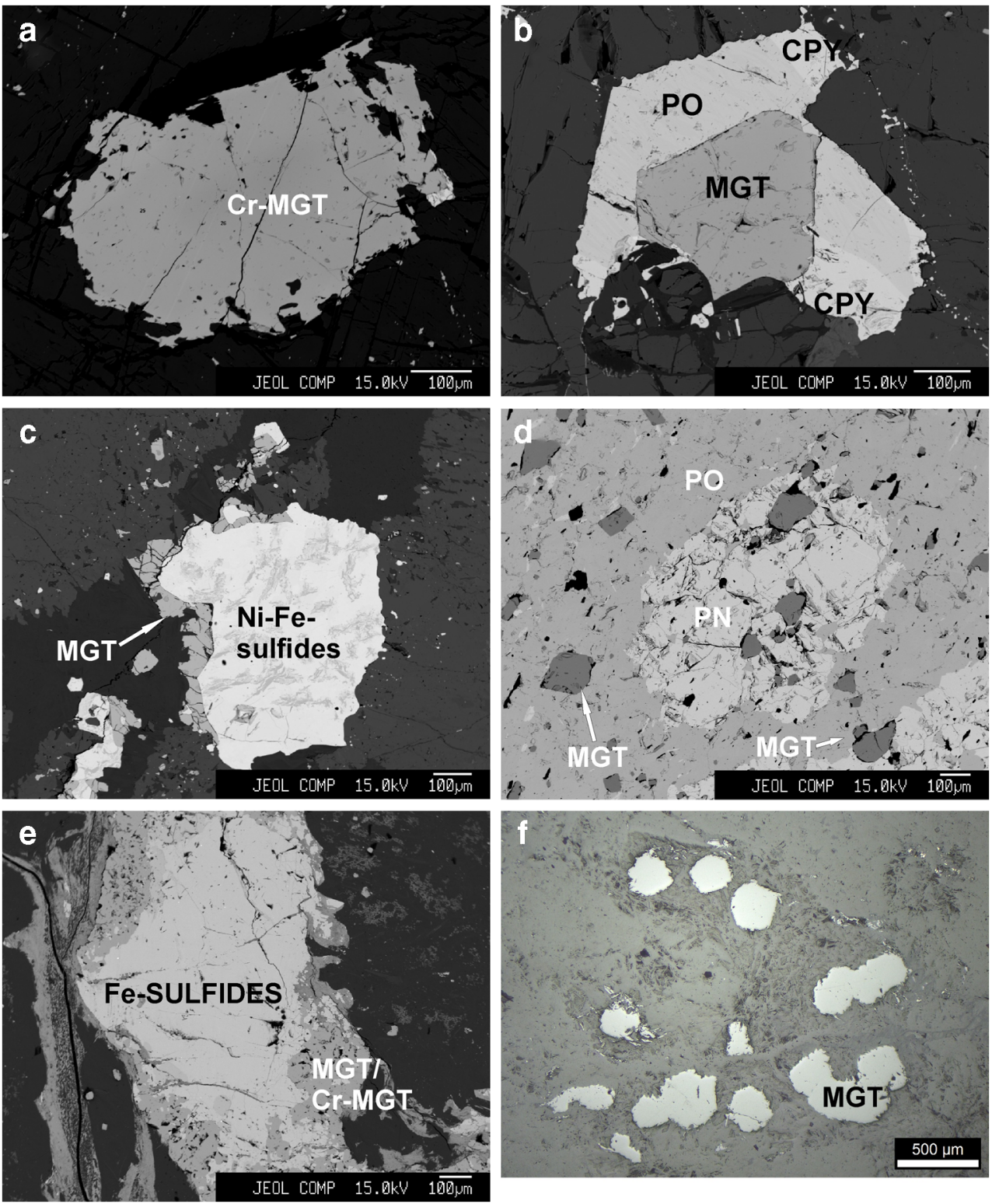

spinel and ilmenite. From the Kevitsa deposit, we studied one sample from each of the three main disseminated ore types, which are called the Normal Ore (Fig. 3b), Ni-PGE Ore (Fig. 3c), and False Ore, with the last one being very low in base metals (Mutanen 1997; Luolavirta et al. 2017). The Normal and False Ore samples contain euhedral-subhedral Cr-magnetite and some magnetite, and the Ni-PGE Ore sample contains mostly subhedral-anhedral magnetite. We also analyzed three samples from a deformed ore body near the margin of the Jinchuan Ni-Cu sulfide deposit, of which two represents $\mathrm{Cu}$-rich remobilized and one a Ni-rich ore (Yang et al. 2018). They contain individual subhedral-anhedral $\mathrm{Cr}$ magnetite grains and magnetite, which occur together with remobilized and sheared disseminated sulfides (Fig. 3e) (Yang et al. 2018). The samples from the Jinchuan deposit were only analyzed with EPMA.

\section{Analytical methods}

\section{Electron probe microanalyzer (EPMA)}

Oxides were analyzed at the Center of Microscopy and Nanotechnology, the University of Oulu, using a Jeol JXA 8200 Superprobe electron probe microanalyzer. In general, 10-30 individual magnetite grains per sample were analyzed. The following analytical conditions were used for oxide analyses: a beam size of $10 \mu \mathrm{m}$, an accelerating potential of $15 \mathrm{kV}$, and a current of $100 \mathrm{nA}$. A large spot size is necessary to prevent over heating of oxides under the high current and to obtain a representative analysis from heterogeneous oxide mineral grains. The peak counting time was set at $30 \mathrm{~s}$ for peaks and $10 \mathrm{~s}$ for the background (expect Fe was set for $6 \mathrm{~s}$ for peak and $3 \mathrm{~s}$ for background). The following 17 elements 

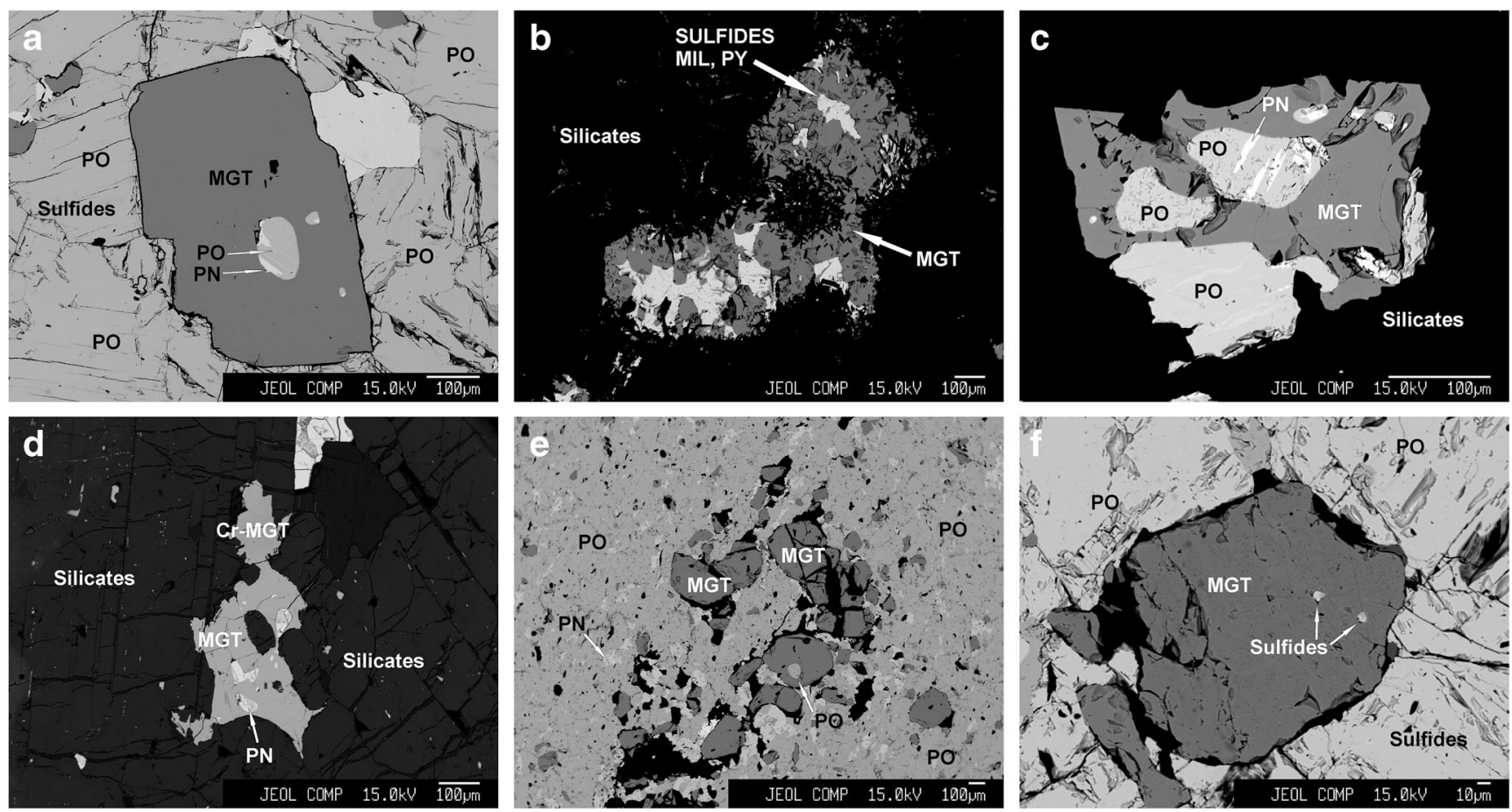

Fig. 4 Back-scattered electron images of sulfide inclusions in magnetites. a Rounded pyrrhotite-pentlandite inclusion in magnetite in a massive sulfide sample from Hietaharju. b Sulfide-magnetite grains from the Vaara deposit. The sulfides enclosed by magnetite are not inclusions sensu stricto, but sulfide-magnetite aggregates have been formed by oxidation of sulfides. c Rounded pyrrhotite-pentlandite inclusions with magnetite in the Lomalampi deposit. d Pentlandite inclusions in magnetites and Cr-magnetites in the Tulppio mineralization. e, f Sulfide inclusions in magnetite from massive sulfide sample in the Pechenga deposit. $\mathrm{CPY}=$ chalcopyrite, $\mathrm{Cr}-\mathrm{MGT}=\mathrm{Cr}$-magnetite, $\mathrm{MGT}=$ magnetite, $\mathrm{MIL}=$ millerite, $\mathrm{PN}=$ pentlandite, $\mathrm{PO}=$ pyrrhotite, $\mathrm{PY}=$ pyrite were analyzed: $\mathrm{Fe}, \mathrm{Ti}, \mathrm{Cr}, \mathrm{V}, \mathrm{Ni}, \mathrm{Cu}, \mathrm{Co}, \mathrm{Mg}, \mathrm{Si}, \mathrm{Al}, \mathrm{Zn}, \mathrm{Mo}$, $\mathrm{Mn}, \mathrm{Pb}, \mathrm{Pt}, \mathrm{Rh}$, and $\mathrm{Ga}$, with the average detection limits falling in the range of $\sim 60-400 \mathrm{ppm}$. The matrix correction with the ZAF method was applied to all oxide analyses.

\section{Laser ablation-inductively coupled plasma-mass spectrometry (LA-ICP-MS)}

Thick $(100 \mu \mathrm{m})$ polished sections were prepared for LA-ICPMS analysis although for some deposits, ordinary thin sections were used. In general, 10-30 individual magnetite grains per section were selected for analysis by LA-ICP-MS. The analyses were performed at the Geological Survey of Finland (GTK) in Espoo using a $\mathrm{Nu}$ AttoM single collector LA-SC-ICP-MS (Nu Instruments Ltd., Wrexham, UK) and an Analyte Excite 193 ArF laser ablation system (Photon Machines, San Diego, USA). The laser was run at a pulse frequency of $10 \mathrm{~Hz}$ and a pulse energy of $5 \mathrm{~mJ}$ at $30 \%$ attenuation to produce an energy flux of $2.5 \mathrm{~J} / \mathrm{cm}^{2}$ on the sample surface with a $40 \mu \mathrm{m}$ spot size (expect from one sample both from Tulppio and Kovero, where the spot size was $25 \mu \mathrm{m}$ ). Analyses were made using time resolved analysis (TRA) with continuous acquisition of data ( $20 \mathrm{~s}$ of baseline followed by $40 \mathrm{~s}$ with laser switched on) for each set of data points ( 2 standards, 10-20 unknown, 1 quality control standard). The solid synthetic silicate GSE-1G standard was used for external standardization, the synthetic glass standards GSD-1G, BCR2G, and BHVO2G for quality control (Guillong et al. 2005; Jochum et al. 2005), and ${ }^{57} \mathrm{Fe}$ as an internal standard. The value of the internal standard has been re-calculated based on the sum of the two main cations ( $\mathrm{Fe}$ and $\mathrm{Cr}$ ), to $100 \%$ (Fe$\mathrm{Cr}_{2} \mathrm{O}_{3}$ ) concentration when the $\mathrm{Cr}$ concentrations were too high (totals above $100 \%$ when using EPMA data). The measurements were performed over 42 isotopes and 34 elements at low resolution $(\Delta \mathrm{M} / \mathrm{M}=300)$ using the fast scanning mode. The following 42 isotopes were analyzed: ${ }^{24} \mathrm{Mg},{ }^{27} \mathrm{Al},{ }^{29} \mathrm{Si}$, ${ }^{30} \mathrm{Si},{ }^{31} \mathrm{P},{ }^{33} \mathrm{~S},{ }^{34} \mathrm{~S},{ }^{43} \mathrm{Ca},{ }^{44} \mathrm{Ca},{ }^{45} \mathrm{Sc},{ }^{47} \mathrm{Ti},{ }^{51} \mathrm{~V},{ }^{52} \mathrm{Cr},{ }^{53} \mathrm{Cr},{ }^{55} \mathrm{Mn}$, ${ }^{57} \mathrm{Fe},{ }^{59} \mathrm{Co},{ }^{60} \mathrm{Ni},{ }^{63} \mathrm{Cu},{ }^{66} \mathrm{Zn},{ }^{71} \mathrm{Ga},{ }^{74} \mathrm{Ge},{ }^{75} \mathrm{As},{ }^{77} \mathrm{Se},{ }^{89} \mathrm{Y},{ }^{90} \mathrm{Zr}$, ${ }^{91} \mathrm{Zr},{ }^{93} \mathrm{Nb},{ }^{95} \mathrm{Mo},{ }^{97} \mathrm{Mo},{ }^{105} \mathrm{Pd},{ }^{117} \mathrm{Sn},{ }^{118} \mathrm{Sn},{ }^{119} \mathrm{Sn},{ }^{139} \mathrm{La}$, ${ }^{147} \mathrm{Sm},{ }^{172} \mathrm{Yb},{ }^{178} \mathrm{Hf},{ }^{181} \mathrm{Ta},{ }^{182} \mathrm{~W},{ }^{195} \mathrm{Pt}$, and ${ }^{208} \mathrm{~Pb}$. The following isotopes were selected for elements for which multiple isotopes were measured: ${ }^{29} \mathrm{Si},{ }^{33} \mathrm{~S},{ }^{43} \mathrm{Ca},{ }^{53} \mathrm{Cr},{ }^{90} \mathrm{Zr},{ }^{95} \mathrm{Mo}$, and ${ }^{118} \mathrm{Sn}$. Average detection limits ( $99 \%$ confidence) were the following: 0.001-0.002 ppm for Pd and Pt; 0.01-0.1 ppm for $\mathrm{Ta}, \mathrm{Pb}, \mathrm{Nb}, \mathrm{W}, \mathrm{Ga}, \mathrm{Hf}, \mathrm{Y}, \mathrm{La}, \mathrm{Yb}, \mathrm{V}, \mathrm{Ge}, \mathrm{Sm}, \mathrm{Sn}, \mathrm{Co}$, and Sc; 0.1-1 ppm for As, Zr, S, Se, Mo, Mn, Cu, Zn, Mg, P, $\mathrm{Cr}$, and $\mathrm{Al} ; 1-2 \mathrm{ppm}$ for $\mathrm{Ni}$ and $\mathrm{Ti}$; and 5-50 ppm for $\mathrm{Fe}, \mathrm{Si}$, and Ca. In ESM Table 1B (Electronic Supplementary Material), only the element is shown, not the isotope number. Data reduction was conducted using the GLITTER ${ }^{\text {TM }}$ 
software (Van Achterbergh et al. 2001), which allows baseline subtraction, the integration of the signal over a selected time resolved interval, and quantification using known concentrations of the external and internal standards.

\section{Results}

The EPMA data were used to identify and classify different iron oxides and also for calibration of LA-ICP-MS analyses. The LA-ICP-MS method was used for more detailed trace element analysis, because compared to EPMA, it is more accurate for trace elements, and has lower detection limits, and the larger spot size allows determination of a more representative composition. ESM Tables 1 A and B list representative compositions of magnetites and $\mathrm{Cr}$-magnetites based on EPMA and LA-ICP-MS analyses, respectively.

In order to compare the magnetite and Cr-magnetite compositions from different deposits, box-whisker percentile plots (Fig. 5) and multi-element variation diagrams (Fig. 6) are utilized. These plots provide a good overview of the data, allowing observations of many elements at the same time. As shown in Fig. 5, in which only oxides with $<1$ wt. $\% \mathrm{Cr}$ are plotted, relatively large variations in the $\mathrm{Cr}, \mathrm{Ti}, \mathrm{V}, \mathrm{Ni}, \mathrm{Al}$, $\mathrm{Mg}$, and $\mathrm{Ga}$ contents of magnetites from different deposits are observed. High Cr concentrations, mostly above 1000 ppm, are shown by magnetites from the Kovero and the Tainiovaara and Ruossakero deposits. In the Kovero case, the magnetites are most likely primary, as they occur as individual grains without zoning. In the Tainiovaara and Ruossakero deposits, magnetites represent altered chromites, which are now $\mathrm{Cr}$ bearing magnetites. Disseminated magnetites from the Pechenga deposit and Vaara non-mineralized altered cumulates and magnetite veins from the Ruossakero deposit show intermediate $\mathrm{Cr}$ concentrations. Magnetites from the Kevitsa Ni-PGE ore, Lomalampi magnetite veins, Hietaharju massive sulfides, and Vaara deposit have low $\mathrm{Cr}$ concentrations, generally below $100 \mathrm{ppm}$.

The highest Ti values in the data set are in magnetite from Pechenga, Lomalampi, Vaara non-mineralized altered cumulate, Kevitsa Ni-PGE ore, and Tainiovaara and Hietaharju deposits, and the lowest values in magnetite veins from Lomalampi and Ruossakero and disseminated sulfide samples from Ruossakero. The highly variable $\mathrm{Ti}$ and $\mathrm{V}$ concentrations in magnetites from the Pechenga massive sample are due to exsolution of Ti-rich phases in some magnetite grains. The highest $\mathrm{V}$ concentrations (generally $\sim 300 \mathrm{ppm}$ to $\sim 1500 \mathrm{ppm}$, and as high as $5000 \mathrm{ppm}$ in Pechenga) occur in magnetite from the Lomalampi, Kovero, and Vaara non-mineralized altered cumulates and the Pechenga and Hietaharju deposits. Intermediate V concentrations $(\sim 100 \mathrm{ppm}$ to $\sim 300 \mathrm{ppm})$ were measured for magnetite from the Kevitsa, Tainiovaara, Ruossakero, and Vaara deposits and low V (mostly below $\sim 100$ ppm) concentrations for magnetite from both veins type samples from the Lomalampi and Ruossakero deposits.

Nickel shows a wide range of concentrations. High Ni concentrations (mostly $\sim 500$ to $\sim 5000 \mathrm{ppm}$ ) were determined from the Ruossakero magnetite veins and Kevitsa, Vaara, Ruossakero, Pechenga, and Tainiovaara deposits. The Ni concentration from magnetite inside pyrrhotite or pentlandite does not vary in the massive sulfide sample from Pechenga, but $\mathrm{Cr}$ magnetites in this sample have lower $\mathrm{Ni}$ (avg. $\mathrm{Ni} \sim 370$ ppm). Magnetites from the Kovero non-mineralized altered cumulate and Lomalampi deposit show intermediate Ni concentrations (generally $\sim 350$ to $\sim 600 \mathrm{ppm}$ ). The lowest Ni values were measured for magnetite from the Lomalampi magnetite veins, Vaara non-mineralized altered cumulate, and Hietaharju massive sulfides (mostly below $\sim 300$ ppm). The Ni concentration in magnetite of the Hietaharju massive sulfide samples is low regardless of whether magnetite grains are enclosed in pyrrhotite or pentlandite. Copper occurs mostly as trace amounts $(<100 \mathrm{ppm})$ in the analyzed magnetite grains, with only the Vaara deposit showing higher $\mathrm{Cu}$ contents, averaging $225 \mathrm{ppm}$. The Kevitsa Ni-PGE ore and Tainiovaara deposit contain magnetite with relatively high Al contents (above $\sim 350 \mathrm{ppm}$ ) whereas magnetite from the Lomalampi magnetite veins; Vaara and Kovero non-mineralized altered cumulates; Vaara, Lomalampi, and Hietaharju deposits shows intermediate Al values. Magnetite grains from the Ruossakero disseminated sulfide samples, and magnetite veins and Pechenga massive sulfide ore are lowest in Al.

The $\mathrm{Mg}$ concentrations in magnetite are highly variable between $\sim 20$ and $\sim 30,000$ ppm, being highest in the Ruossakero, Tainiovaara, and the Kevitsa deposits $(\sim 1000$ to $30,000 \mathrm{ppm}$ ); intermediate in the Lomalampi and Vaara deposits, Ruossakero magnetite veins and barren cumulates from Kovero and Vaara (mostly $\sim 450$ to $\sim 7000 \mathrm{ppm}$ ); and lowest in massive sulfides from the Pechenga and Hietaharju deposits ( 20 to $\sim 400 \mathrm{ppm})$. Silicon is also low in massive sulfide samples, though it overlaps partly with $\mathrm{Si}$ in other sample types. Interestingly, high Ga concentrations were observed in magnetite from massive sulfide samples from Pechenga and Hietaharju, and also magnetites from the Kevitsa deposit and Lomalampi remobilized magnetite. The LA-ICP-MS data show that levels of Pt and $\mathrm{Pd}$ are mostly below or very close to the detection limit in the analyzed iron oxides (average detection limits in LA-ICPMS analysis for $\mathrm{Pt}$ and $\mathrm{Pd}$ are $\sim 0.001$ and $\sim 0.002 \mathrm{ppm}$, respectively). 

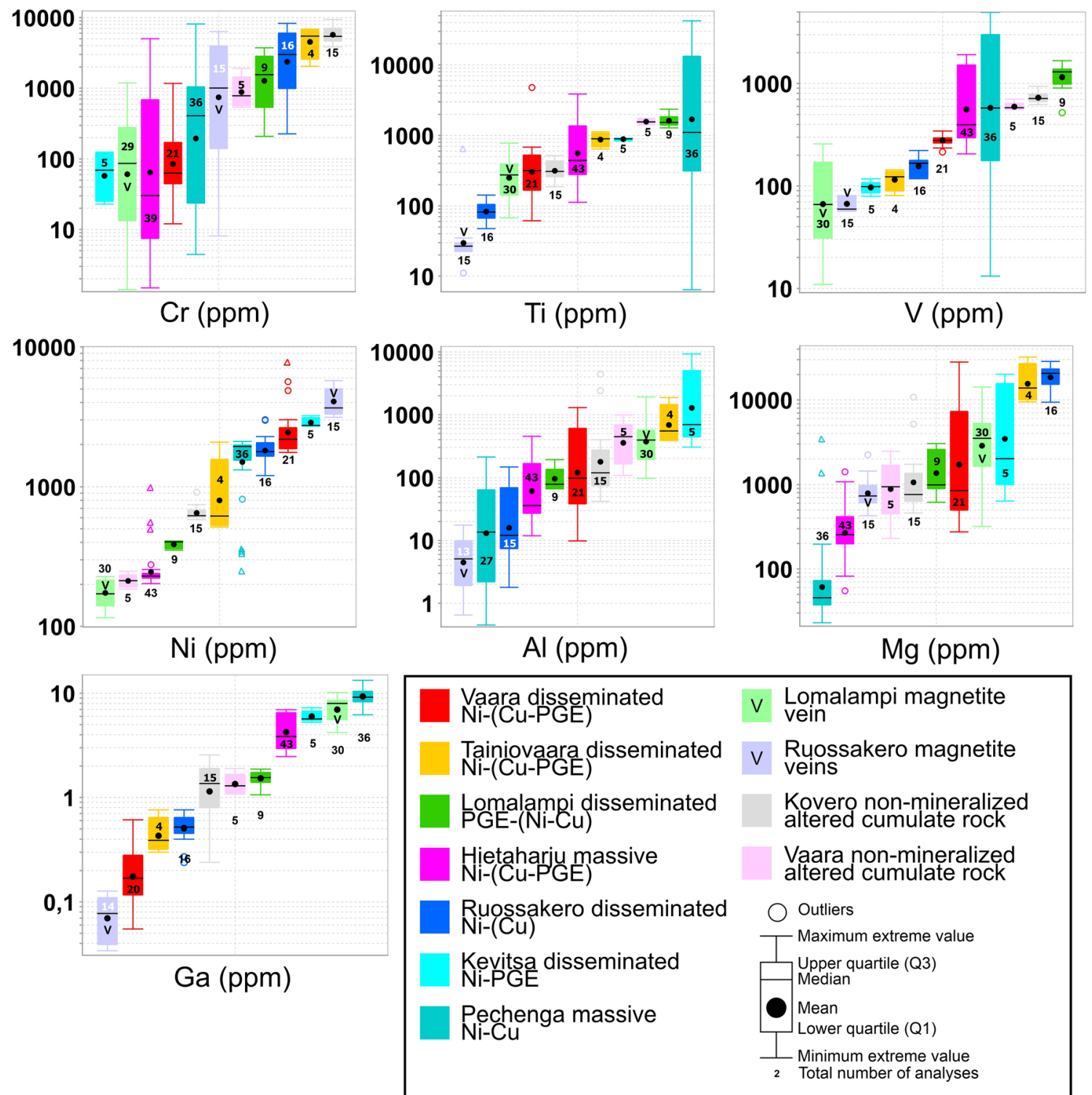

Fig. 5 Box-whisker percentile diagrams of relevant elements in studied magnetites $(\mathrm{Cr}<1$ wt.\%)

In the multi-element variation diagram of Dare et al. (2014) shown in Fig. 6, trace element compositions are shown separately for magnetites from massive sulfide samples (Fig. 6a), from vein samples (Fig. 6b), magnetites from disseminated sulfide samples and some non-mineralized samples (Fig. 6c), and $\mathrm{Cr}$-magnetites from disseminated sulfide samples and some non-mineralized samples (Fig. 6d). Magnetites from the massive sulfide samples from Pechenga and Hietaharju (Fig. 6a) show very similar patterns, which are enriched in $\mathrm{V}, \mathrm{Ni}$, and $\mathrm{Cr}$ compared to continental crust. Interestingly, magnetites from Pechenga have the highest $\mathrm{Ti}, \mathrm{Nb}$, and Ta concentrations in the data set. Magnetite veins from Lomalampi and Ruossakero (Fig. 6b) have mutually similar trends, but the
Lomalampi magnetite veins have more elevated contents of most elements (e.g., $\mathrm{Y}, \mathrm{Al}, \mathrm{Ge}, \mathrm{Sc}, \mathrm{Nb}, \mathrm{Ga}$ ). The exceptions to this are higher $\mathrm{Cr}$ and $\mathrm{Ni}$ contents at Ruossakero. Magnetites from disseminated sulfide samples and some non-mineralized altered samples (Fig. 6c) show relatively uniform trends. They are enriched in $\mathrm{V}, \mathrm{Ni}$, and $\mathrm{Cr}$, especially in the mineralized ones. The Vaara magnetites have higher $\mathrm{Pb}$ and $\mathrm{Cu}$ contents compared to others. Cr-magnetites $(\mathrm{Cr}>1$ wt.\%) in Fig. 6d have relatively similar element distributions between each other. Some differences occur as, for example, the Kevitsa Ni-PGE and Tainiovaara samples have higher $\mathrm{Cu}$ concentrations. All $\mathrm{Cr}$-magnetites are enriched in the more compatible elements (Zn, Co, V, Ni, and $\mathrm{Cr}$ ). 


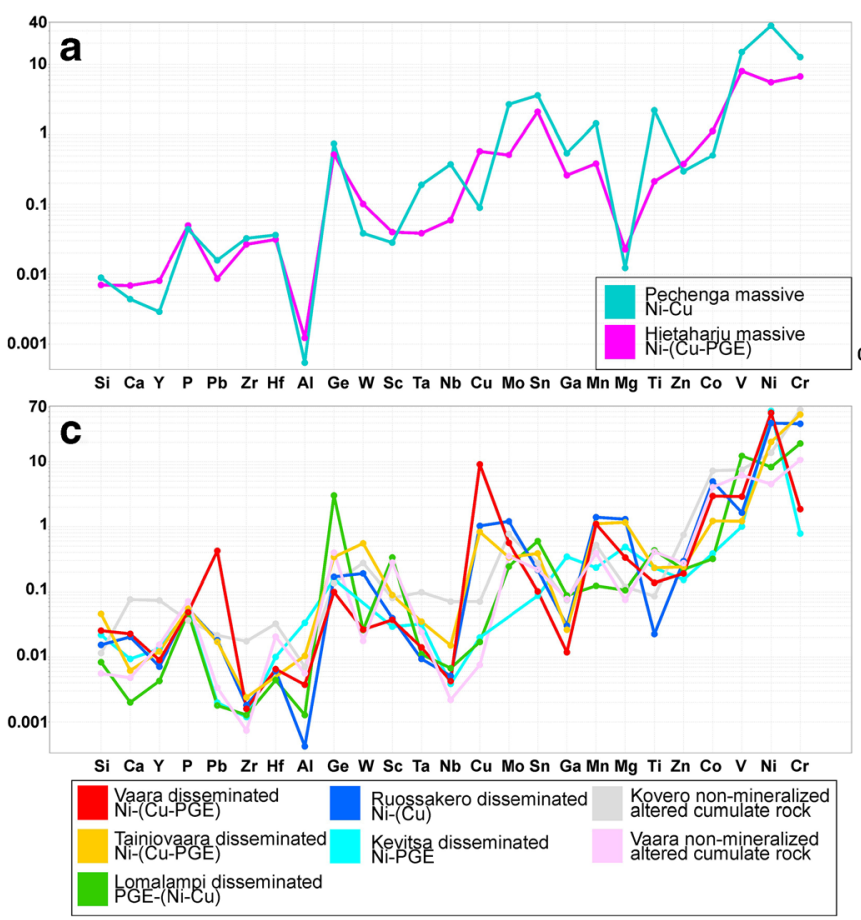

Fig. 6 Bulk continental crust-normalized multi-element diagrams for magnetites and $\mathrm{Cr}$-magnetites ( $>1 \mathrm{wt} . \% \mathrm{Cr}$ ). a Magnetites from massive sulfide samples. b Magnetites from vein samples. c Magnetites from disseminated sulfide samples and some non-mineralized samples. $\mathbf{d ~ C r}$ magnetites from disseminated sulfide samples and some non-mineralized

In Fig. 7, magnetite compositions from the studied deposits are compared with the fields showing magnetite compositions in different stages of sulfide fractionation as defined by Dare et al. (2012) and Boutroy et al. (2014) using magnetites from the Sudbury Ni-Cu sulfide deposits. These fields represent early-forming Fe-rich MSS (monosulfide solid solution), evolved Fe-rich, and residual Cu-rich ISS (intermediate solid solution). Dare et al. (2012) observed that in sulfide liquid, lithophile elements (Cr, Ti, V, Al, Mn, Sc, Nb, Ga, Ge, Ta, Hf, W, and $\mathrm{Zr}$ ) are compatible into iron oxides. In early-forming magnetite, which crystallizes with Fe-rich MSS, lithophile elements occur in the highest concentrations, and when fractionation of sulfide liquid continues towards a $\mathrm{Cu}$ rich ISS, the concentration of these elements in magnetite gradually decrease, becoming low in magnetite, which crystallizes with the residual ISS (Dare et al. 2012). In the $\mathrm{Cr}$ vs. V, Ti, and Ni diagrams (Fig. 7a, b, and c), a clear horizontal trend can be observed due to varying $\mathrm{Cr}$ concentrations in magnetites, which likely indicates that oxide grains represent highly altered chromites. In the $\mathrm{Cr}$ vs. V binary diagram (Fig. 7a), most of the magnetite grains from the Pechenga sample are in the primitive Fe-

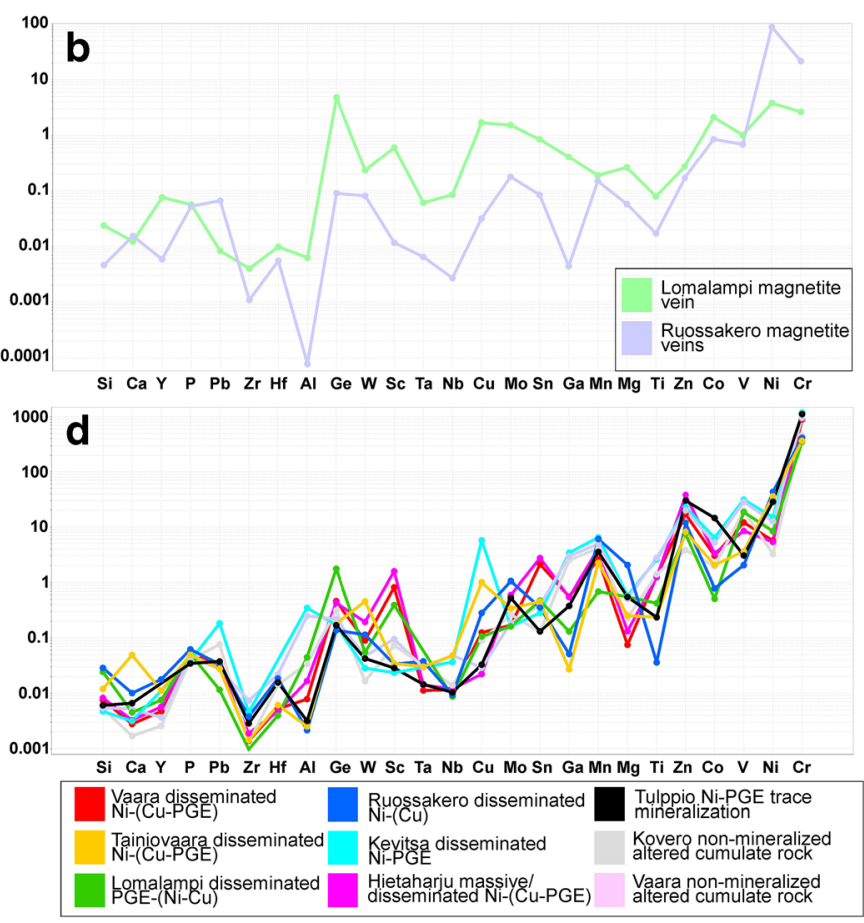

samples. The element compatibility into magnetite increases from left to right (Dare et al. 2014). Compositions were determined with LA-ICPMS. Normalization values of continental crust are from Rudnick and Gao (2003)

rich and evolved Fe-rich fields (MSS) (Fig. 7a), and most of the Vaara and Kevitsa magnetite grains plot in the evolved Fe-rich field. Some of the magnetite compositions from the Hietaharju massive sulfide samples are in the primitive and evolved Fe-rich fields. Magnetite from the Lomalampi deposit occurs mostly inside the primitive $\mathrm{Fe}$ rich field. Other compositions from Tainiovaara, Ruossakero, and Kovero are located mostly outside of these fields.

The Cr vs. Ni diagram (Fig. 7b and Fig. 8) shows that most of the magnetite grains analyzed from the mineralized sulfide samples are high in Ni and some are close to the $\mathrm{Cu}$-rich (ISS) field. The Cr vs. Ti diagram (Fig. 7c) indicates similar features to those of the Cr vs. V diagram, mostly due to the positive correlation between Ti and V (Fig. 7d). The variation in Ti and $\mathrm{V}$ abundances could be explained by some amount of fractionation of sulfide liquid. It is worth pointing out that in the Pechenga massive ore sample, there is a continuous variation from $\mathrm{Cr}$-magnetite to very $\mathrm{Cr}$-poor magnetite, with $\mathrm{Cr}$ varying from $\sim 43,000$ to $\sim 5$ ppm (Fig. $7 \mathrm{a}-\mathrm{c}$ ). In the $\mathrm{Cr}$ vs. Ti diagram, some of the magnetite compositions from the Hietaharju, Vaara, Kevitsa, and Pechenga deposits plot in the $\mathrm{Cu}$-rich (ISS) field. 

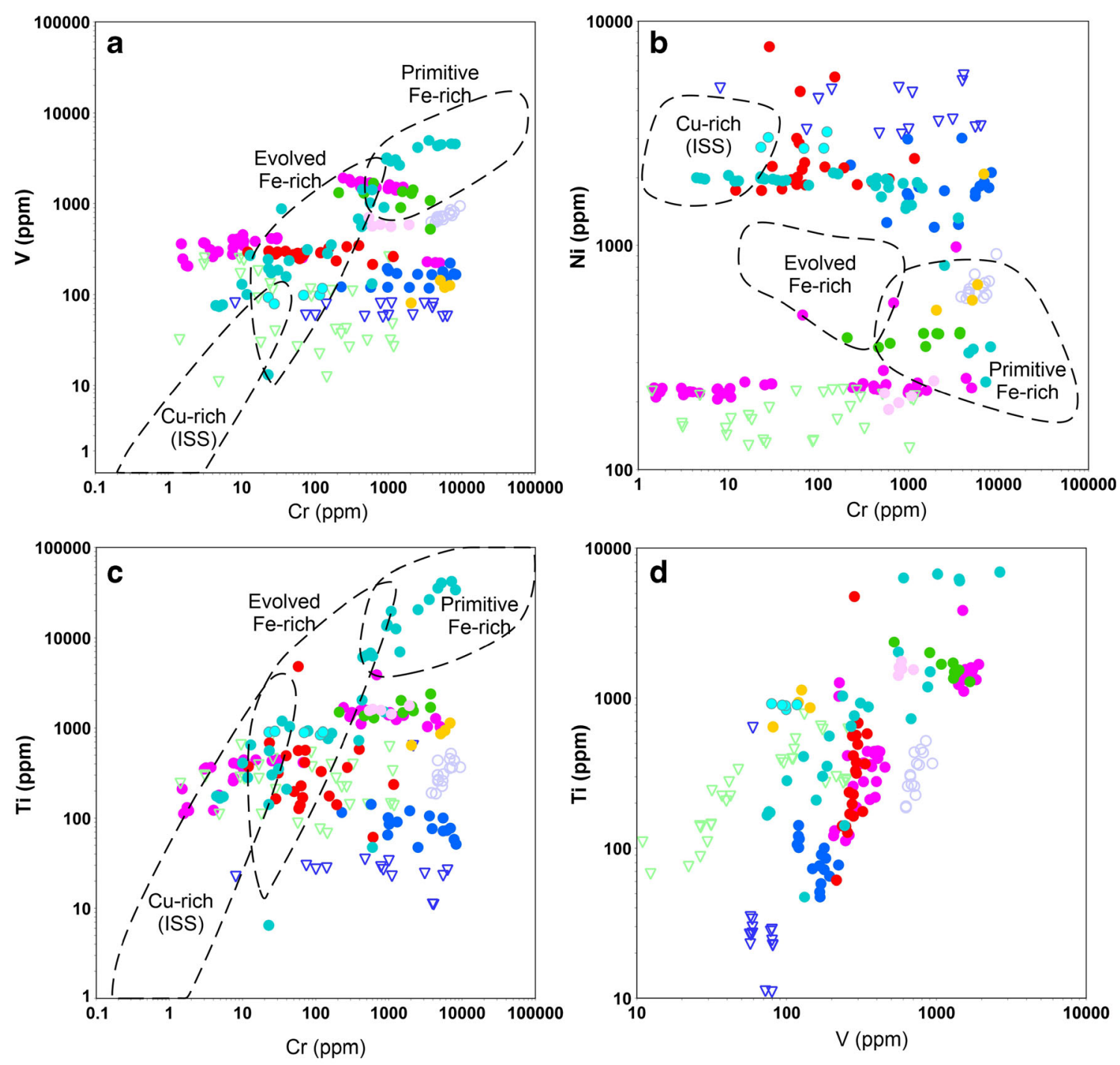

\begin{tabular}{|lll|}
\hline - Vaara disseminated & - Ruossakero disseminated & Pechenga massive \\
Ni-(Cu-PGE) & Ni-Cu \\
Tainiovaara disseminated & $\nabla$ Ruossakero Ni-(Cu) & Kovero non-mineralized \\
Ni-(Cu-PGE) & veins & altered cumulate rock \\
- Lomalampi disseminated & Kevitsa disseminated & Vaara non-mineralized \\
PGE-(Ni-Cu) & Ni-PGE & altered cumulate rock \\
$\nabla \begin{array}{l}\text { Lomalampi PGE-(Ni-Cu) } \\
\text { veins }\end{array}$ & $\begin{array}{c}\text { Hietaharju massive } \\
\text { Ni-(Cu-PGE) }\end{array}$ & \\
\hline
\end{tabular}

Fig. 7 Binary plots for magnetite compositions. a Cr vs. V. b Cr vs. Ni. c Cr vs. Ti. d V vs. Ti. Sulfide evolution trend fields defined from magnetite compositions from Sudbury in $\mathbf{a}, \mathbf{b}$, and $\mathbf{c}$ are taken from Boutroy et al. (2014) and original data are from Dare et al. (2012)

\section{Discussion}

\section{Magnetite composition as an indicator of its origin}

In Fig. 7, most of the magnetite grains from the massive sulfide samples from the Pechenga and Hietaharju deposits plot in the primitive Fe-rich (MSS) and evolved Fe-rich (MSS) fields, which indicates that they crystallized with MSS, also minor amounts with ISS. These magnetite grains from the massive sulfide samples also show low-Mg contents (Fig. 5). The early-formed magnetites which crystallized with a primitive Fe-rich MSS at Sudbury have similarly anomalously low-Mg concentrations (Dare et al. 2012). Magnetites from disseminated sulfide samples from Vaara and Kevitsa also plot mostly in the Fe-rich (MSS) and evolved Fe-rich (MSS) fields, and some analyses also in the ISS field. Also, 


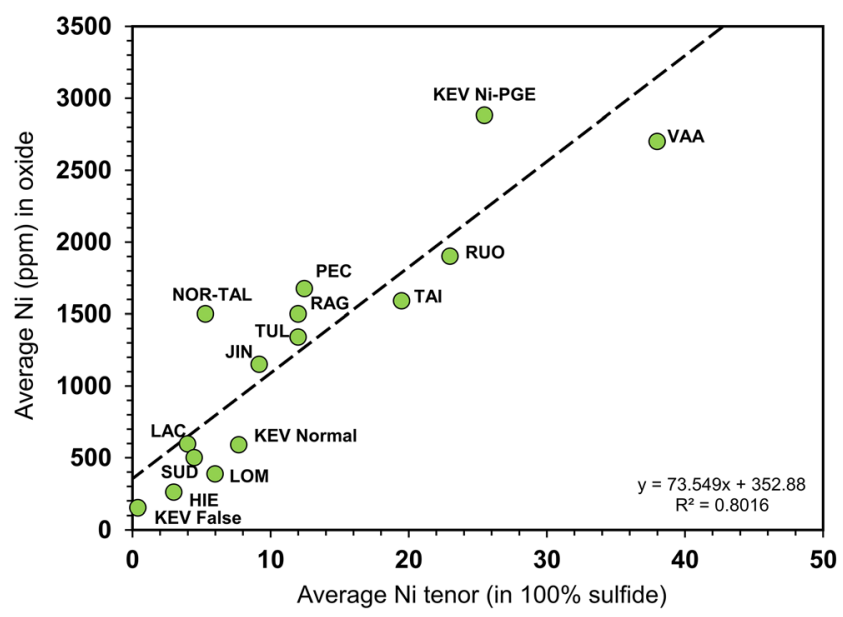

Fig. $8 \mathrm{Ni}$ tenor vs. Ni concentration in oxide based on LA-ICP-MS (except for Jinchuan EPMA data was used) data from this study and literature. Abbreviations of deposits and mineralizations and references to other data sources for magnetite concentration Ni tenor data: $\mathrm{HIE}=$ Hietaharju (Konnunaho et al. 2015), JIN = Jinchuan (Naldrett 2004 and references therein), KEV=Kevitsa (Mutanen 1997; Yang et al. 2013), LAC $=$ Lac des Iles (Duran et al. 2016; Djon et al. 2018), LOM= Lomalampi (Konnunaho et al. 2015), NOR-TAL = Noril'sk-Talnak (Naldrett 2004; Boutroy et al. 2014), PEC=Pechenga (Naldrett 2004; Boutroy et al. 2014), RAG $=$ Raglan (Naldrett 2004; Boutroy et al. 2014; Osmond et al. 2002), RUO = Ruossakero (Konnunaho et al. 2015), SUD = Sudbury (Naldrett 2004; Boutroy et al. 2014); TUL = Tulppio; VAA = Vaara (Konnunaho et al. 2015)

some of the magnetites in the disseminated sulfide samples from the Lomalampi deposit plot in the Fe-rich and evolved MSS fields (Fig. 7a). These magnetites from mineralized samples are also enriched in $\mathrm{V}, \mathrm{Ni}$, and $\mathrm{Cr}$, which indicates that they crystallized with MSS-ISS.

One difference between magnetites from massive sulfide samples and disseminated sulfide samples is that magnetites in the former have lower $\mathrm{Mg}$ and higher $\mathrm{Ga}$ (Figs. 5 and 6), similar to magnetites in primitive Fe-rich MSS in the Sudbury ores (Dare et al. 2012). Interestingly, most of the magnetite compositions from the Vaara deposit plot in the evolved Fe-rich (MSS) field (Fig. 7a, c), despite the fact that magnetites are mostly formed in post-magmatic hydrothermal oxidation of sulfides. Also, copper and lead are higher in the Vaara magnetites than in magnetites in the other deposits (Fig. 6c), a phenomenon potentially related to the oxidation of sulfides to magnetite. In contrast, magnetite compositions from postmagmatically altered samples from the Ruossakero and Tainiovaara deposits plot clearly outside of the MSS-ISS fields (Fig. 7), potentially indicating that their original magmatic composition is hydrothermally altered.

Hydrothermal magnetite veins in the Lomalampi and Ruossakero deposits have low $\mathrm{Ti}$ and $\mathrm{V}$ concentrations compared to other magnetite occurrence styles (Fig. 5). The Lomalampi magnetite veins are also enriched in Ga. Interestingly, magnetite veins from the Ruossakero deposit are highly enriched in Ni. These vein-type magnetites plot in the hydrothermal field in Fig. 9a and have a relatively high $\mathrm{Si}+\mathrm{Mg}$ content (Fig. 9c).

In general, Cr-magnetites can be formed by different mechanisms, including direct crystallization from a silicate magma or from a sulfide liquid, post-magmatic alteration of Cr-spinel, or during metamorphic and/or hydrothermal redox processes without a $\mathrm{Cr}$-spinel precursor. $\mathrm{Cr}$ magnetites analyzed in this study are enriched in $\mathrm{Zn}, \mathrm{Co}$, $\mathrm{V}$, and Ni (Fig. 6d). Most samples with disseminated sulfides contain $\mathrm{Cr}$-magnetites with clear petrographic evidence that they formed by alteration of magmatic $\mathrm{Cr}$-spinel. The contents of Ti, Cr. and V vary in the analyzed $\mathrm{Cr}$ magnetites. The highest $\mathrm{Cr}$ concentration occurs in magnetites that are most likely altered from chromites. $\mathrm{Cr}$ magnetites in the massive sulfide sample from Pechenga have the highest $\mathrm{V}$ and Ti concentrations among the analyzed $\mathrm{Cr}$-magnetites. Depending on the $\mathrm{Cr}$ content and alteration intensity, $\mathrm{Zn}$ is relatively high in $\mathrm{Cr}$-magnetites (Fig. 6d), and in this case, the high $\mathrm{Zn}$ content is related to chromium spinel alteration (cf. Barnes 2000). The Pechenga massive sulfide samples with a continuous chemical variation between $\mathrm{Cr}$-magnetite and magnetite demonstrate that $\mathrm{Cr}$-magnetite can crystallize directly from sulfide liquid. In contrast to $\mathrm{Cr}$, Ni shows a more constant concentration of around $2000 \mathrm{ppm}$. The difference in the behavior of these two metals could be related to lowtemperature sulfide-oxide equilibration which affected $\mathrm{Ni}$ but not $\mathrm{Cr}$.

In several disseminated sulfide deposits, $\mathrm{Cr}$-magnetite occurs as a dissemination together with sulfides (Fig. 2b, $d, e)$. They could have been formed near or at the boundary between sulfide and silicate liquids via diffusion of oxygen out of the sulfide liquid (Frost and Groves 1989; Fonseca et al. 2008), but because of the highly altered and deformed nature of the rocks, this is hard to prove. Cr-magnetites in the Hietaharju sheared and disseminated sulfide sample (Fig. $2 \mathrm{~b}$ ) are low in $\mathrm{Ni}$ (avg. $\sim 250 \mathrm{ppm}$ ). In the Vaara disseminated ore representing complete oxidation of the original sulfide assemblage to Ni-rich sulfides and magnetites, Cr-magnetite does not occur, but the oxide phase (magnetite) is enriched in $\mathrm{Ni}$ (avg. $\sim 2000 \mathrm{ppm}$ ), with the $\mathrm{Cr}$ content being generally at a level of 10-100 ppm.

In the komatiite-hosted deposits, such as Vaara, Ruossakero, and Lomalampi, magnetite compositions are low in $\mathrm{Nb}$ and $\mathrm{Ta}$ (below or very close to the detection limits), which obviously is a consequence of 

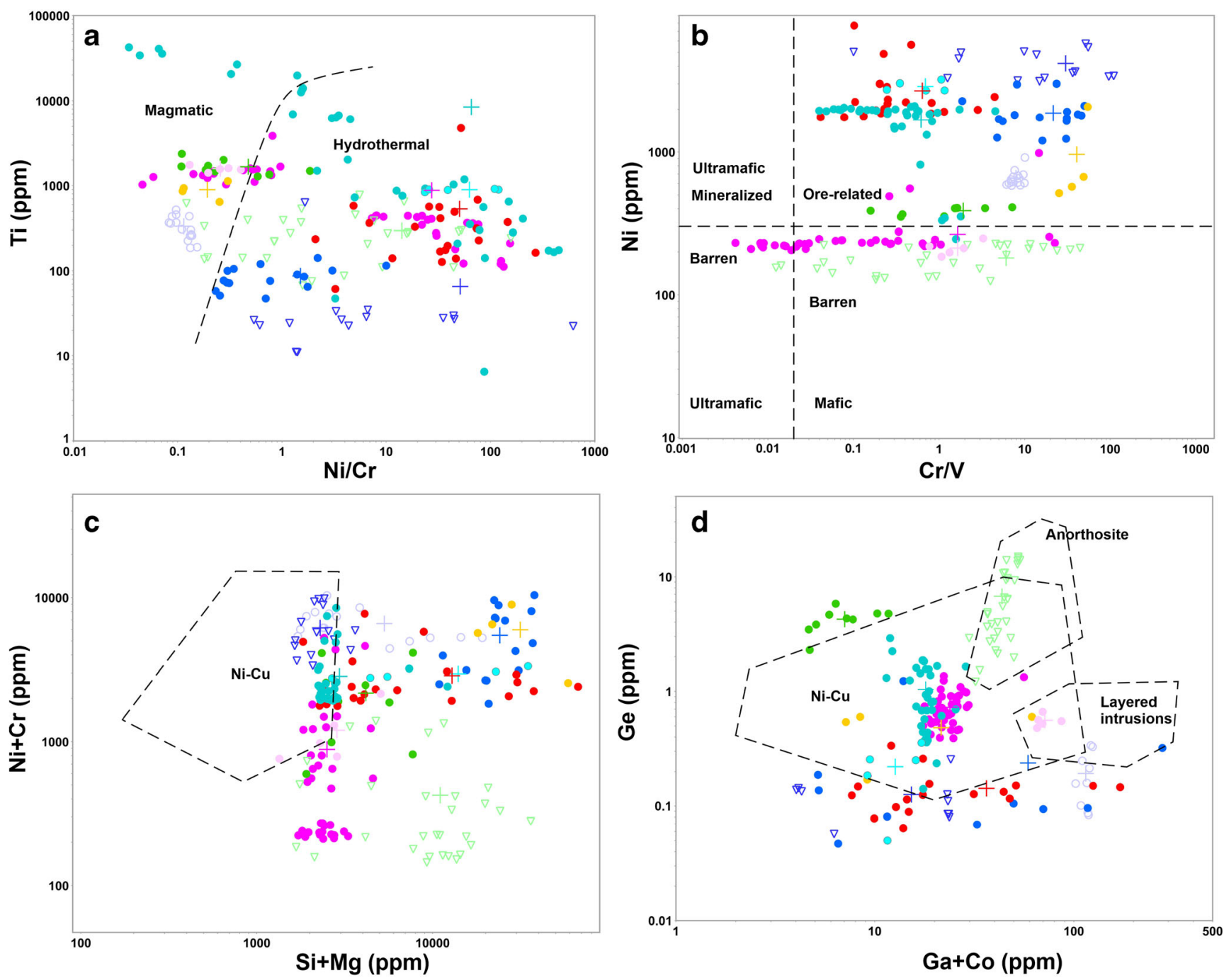

\begin{tabular}{|c|c|c|c|}
\hline & $\begin{array}{l}\text { Vaara disseminated } \\
\text { Ni-(Cu-PGE) }\end{array}$ & - Ruossakero disseminated & $\begin{array}{l}\text { - Pechenga massive } \\
\text { Ni-Cu }\end{array}$ \\
\hline$\bullet$ & $\begin{array}{l}\text { Tainiovaara disseminated } \\
\text { Ni-(Cu-PGE) }\end{array}$ & $\nabla \begin{array}{l}\text { Ruossakero } \mathrm{Ni}-(\mathrm{Cu}) \\
\text { veins }\end{array}$ & $\begin{array}{l}\text { Kovero non-mineralized } \\
\text { altered cumulate rock }\end{array}$ \\
\hline$\bullet$ & $\begin{array}{l}\text { Lomalampi disseminated } \\
\text { PGE-(Ni-Cu) }\end{array}$ & $\begin{array}{l}\text { Kevitsa disseminated } \\
\text { Ni-PGE }\end{array}$ & $\begin{array}{l}\text { Vaara non-mineralized } \\
\text { altered cumulate rock }\end{array}$ \\
\hline$\nabla$ & $\begin{array}{l}\text { Lomalampi PGE-(Ni-Cu) } \\
\text { veins }\end{array}$ & $\begin{array}{l}\text { Hietaharju massive/ } \\
\text { disseminated Ni-(Cu-PGE) }\end{array}$ & + Mean \\
\hline
\end{tabular}

Fig. 9 Different discrimination diagrams for magnetite compositions. Based on LA-ICP-MS data. a Ni/Cr vs. Ti diagram (Dare et al. 2014). b $\mathrm{Cr} / \mathrm{V}$ vs. Ni diagram (Ward et al. 2018). c Si + Mg vs. $\mathrm{Cr}+\mathrm{Ni}$ diagram

their komatiitic parental magma. In contrast, magnetites from the Pechenga massive sulfide samples show an average concentration of 4.5 and $0.17 \mathrm{ppm}$ for $\mathrm{Nb}$ and $\mathrm{Ta}$, respectively, and their $\mathrm{Ti}$ concentrations are also high (avg. mean 2300 ppm, Fig. 5), which all can be regarded as reflections of the ferropicritic parental magma with an OIB-type trace element signature (Hanski and Smolkin 1995). with $\mathrm{Ni}-\mathrm{Cu}$ area, which is field of $\mathrm{Ni}-\mathrm{Cu}$ sulfide deposits (Dupuis and Beaudoin 2011). d Ga + Co vs. Ge diagram (Liu et al. 2015)

\section{Correlation between $\mathrm{Ni}$ tenor and $\mathrm{Ni}$ content in magnetite}

Figure 8 shows average Ni concentrations of iron oxides compared with the average Ni tenors (percentage of $\mathrm{Ni}$ in 100\% sulfide) of the corresponding ore deposits, including data from this study and the literature. The Kevitsa Ni-PGE, Vaara, and Ruossakero mineralized samples show the highest $\mathrm{Ni}$ contents 
(LA-ICP-MS data) in the oxides, with the average Ni content being as high as $\sim 2900 \mathrm{ppm}, \sim 2700 \mathrm{ppm}$, and $\sim 1900 \mathrm{ppm}$ in these three cases, respectively. This is consistent with their high average Ni tenors of $\sim 25 \mathrm{wt} . \%, \sim 38 \mathrm{wt} . \%$, and $\sim 23 \mathrm{wt} . \%$, respectively (Mutanen 1997; Yang et al. 2013; Konnunaho et al. 2015). Interestingly, in the Vaara and Ruossakero deposits, magnetite is accompanied with Ni-rich sulfides, such as millerite and violarite (Konnunaho et al. 2015). High Ni sulfides also occur in the Kevitsa deposit in association with ultranickeliferous olivine (Mutanen 1997; Yang et al. 2013). Similarly, the Tainiovaara deposit has a relatively high $\mathrm{Ni}$ tenor, $\sim 20$ wt.\% (Konnunaho et al. 2015), and relatively high $\mathrm{Ni}$ contents (average $\sim 1600 \mathrm{ppm}$ ) in Cr-magnetite and magnetite. The Raglan, Noril'sk-Talnakh, and Pechenga ore deposits show moderately high average $\mathrm{Ni}$ tenors, $\sim 12 \mathrm{wt} . \%, \sim 5 \mathrm{wt} . \%$, and $\sim 12.5 \mathrm{wt} . \%$, respectively, and their average Ni contents in oxides are also moderately high, $\sim 1500 \mathrm{ppm}, \sim 1500 \mathrm{ppm}$, and $\sim 1700 \mathrm{ppm}$, respectively (Osmond et al. 2002; Boutroy et al. 2014; Naldrett 2004). The Jinchuan deposit has an average Ni tenor of $\sim 9 \mathrm{wt} . \%$ (Naldrett 2004) and an average $\mathrm{Ni}$ concentration in $\mathrm{Cr}$ magnetites of $\sim 1150 \mathrm{ppm}$, whereas magnetite is very low in $\mathrm{Ni}$ (below the EPMA detection limit; the average detection limit for $\mathrm{Ni}$ varied from $\sim 50$ to $\sim 200 \mathrm{ppm}$ ). The Tulppio Cr-magnetites have an average $\mathrm{Ni}$ content of $\sim 1300 \mathrm{ppm}$ and an average $\mathrm{Ni}$ tenor of the Tulppio mineralization is $\sim 12 \mathrm{wt} . \%$. Cr-magnetites could in some cases represent chromite alteration products, and therefore, the Ni concentrations do not necessarily represent those of magnetite or Cr-magnetite that crystallized from a sulfide liquid. The oxide phase in the Lac Des Iles (Canada), Sudbury and Kevitsa Normal Ores has an average Ni concentration of $\sim 500-600 \mathrm{ppm}$, with the corresponding Ni tenors being $\sim 4$ wt. $\%, \sim 4.5$ wt. $\%$, and $\sim 8$ wt. $\%$, respectively (Mutanen 1997; Naldrett 2004; Yang et al. 2013; Boutroy et al. 2014; Duran et al. 2016; Djon et al. 2018). The Lomalampi and Hietaharju deposits show generally lower Ni tenors, averaging $\sim 6 \mathrm{wt} . \%$ and $\sim 3 \mathrm{wt} . \%$, respectively, and their magnetites are also lower in $\mathrm{Ni}$, averaging $400 \mathrm{ppm}$ and $250 \mathrm{ppm}$, respectively. Of the studied deposits, the Kevitsa False Ore has the lowest average Ni concentration in magnetite $(\sim 150 \mathrm{ppm})$, which is coupled with the lowest Ni tenor of $\sim 0.5$ wt.\% (Mutanen 1997; Yang et al. 2013).

In Fig. 8, average Ni tenors obtained from the literature for each deposit as a whole were used, though the tenor can vary much within a deposit and between different types of ores within a deposit. Nevertheless, this plot shows a relatively good positive correlation between the average Ni tenor of sulfides and the average Ni content of oxides. Furthermore, the diagram demonstrates that the correlation is valid regardless of the post-magmatic history of the deposits, as a high $\mathrm{Ni}$ content of magnetite can be both due to post-magmatic oxidation of sulfides (as in the case of the Vaara, Ruossakero, and Tainiovaara deposits) or a primary feature related to a high $\mathrm{Ni}$ content of the silicate magma and consequently that of the sulfide liquid from which these Fe oxides crystallized (as exemplified by Kevitsa). It may be that in both cases, late sulfide-magnetite equilibration took place at relatively low temperatures.

In considering the relationship between the $\mathrm{Ni}$ tenor and the $\mathrm{Ni}$ content of associated oxides, we used average Ni tenors from the literature. This phenomenon should be examined further employing controlled sampling in detailed scale, with the tenor calculated and magnetite composition measured from the same sample, potentially also involving other elements, such as $\mathrm{Co}$ and $\mathrm{Cu}$.

\section{Application to mineral exploration}

Several recent studies have focused on attempts to employ the magnetite trace element composition as an exploration tool for $\mathrm{Ni}-\mathrm{Cu}-\mathrm{PGE}$ deposits and as a key to the origin of magnetite. Dare et al. (2014) presented a Ni/Cr vs. Ti diagram, which can discriminate between magmatic and hydrothermal magnetite, and Dupuis and Beaudoin (2011) introduced a $\mathrm{Cr}+\mathrm{Ni}$ vs. $\mathrm{Si}+\mathrm{Mg}$ diagram to discriminate magnetite between $\mathrm{Ni}-\mathrm{Cu}-$ PGE deposits and hydrothermal and other types of magmatic ore deposits. Ward et al. (2018) showed that the $\mathrm{Cr} / \mathrm{V}$ ratio vs. Ni diagram can be used to distinguish magnetite generations that were formed in mineralized and barren systems. Liu et al. (2015) introduced a $\mathrm{Ga}+\mathrm{Co}$ vs. Ge diagram, which can discriminate magnetite from $\mathrm{Ni}-\mathrm{Cu}$ deposits, massif-type anorthosites, and evolved parts of mafic-layered intrusions. In addition to magnetite, the chemical composition of chromite can be useful in mineral exploration for magmatic sulfide deposits. For example, the recent study by Locmelis et al. (2018) demonstrated that the Ru (or other PGE) content in chromite is indicative of the presence or absence of a sulfide liquid during the crystallization of chromite.

In Fig. 9, our magnetite data are plotted on the four discrimination diagrams mentioned above. It is important to note that all the studied samples are more or less altered, and therefore, these discrimination diagrams cannot be used to directly discriminate their origin but, instead, can be used to discuss the variation in the chemical composition of iron oxides during alteration. We filtered out Cr-bearing magnetites from these plots (exclusively plotting magnetites with $\mathrm{Cr}<$ $1 \mathrm{wt} . \%)$ to exclude the grains that may have originally been chromites. Figure 9a presents the $\mathrm{Ni} / \mathrm{Cr}$ vs. Ti diagram (Dare et al. 2014), where most of the magnetite compositions from Tainiovaara and Lomalampi together with non-mineralized 
altered cumulates from Vaara and Kovero plot in the magmatic magnetite field. The magnetite composition from the Pechenga and Hietaharju deposits fall both in the magmatic and hydrothermal field. Instead, due to their high Ni concentrations, most of the magnetite analyzed from Vaara, Ruossakero, Kevitsa, and Lomalampi magnetite veins plot in the hydrothermal field.

In the $\mathrm{Cr}+\mathrm{Ni}$ vs. $\mathrm{Si}+\mathrm{Mg}$ diagram (Dupuis and Beaudoin 2011), most magnetite from Pechenga and Ni-rich magnetite veins from Ruossakero plot in the $\mathrm{Ni}-\mathrm{Cu}$ sulfide ore field (Fig. 9c). Some magnetite from Hietaharju, Vaara, and Kovero are also in the Ni-Cu field. However, other compositions are outside of the $\mathrm{Ni}-\mathrm{Cu}$ field due to their relatively high $\mathrm{Si}$ and $\mathrm{Mg}$ concentrations. This is most likely because of the alteration of the samples. In the $\mathrm{Cr} / \mathrm{V}$ vs. Ni diagram (Ward et al. 2018), all the magnetite compositions from the Lomalampi, Kevitsa, Vaara, Pechenga, and Tainiovaara deposits are inside the ore-related field (Fig. 9b). Interestingly, magnetites from Kovero occur also in this field, though currently no $\mathrm{Ni}-\mathrm{Cu}$ sulfide mineralization is known to exist in the Kovero area. Most of the analyzed magnetites from the Hietaharju deposit plot in the barren field, with only two compositions being located in the ore-related field. This is because of their anomalously low Ni concentrations, which is an enigmatic feature given the fact that magnetite occurs in massive Ni-rich ore. Also, the magnetite grains from Lomalampi and magnetite veins and a non-mineralized altered cumulate sample from Vaara are in the barren field. Using the $\mathrm{Ga}+\mathrm{Co}$ vs. Ge diagram of Liu et al. (2015), the analyzed magnetites from Pechenga, Tainiovaara, Hietaharju, and Kevitsa deposits plot in the $\mathrm{Ni}-\mathrm{Cu}$ field (Fig. 9d). Magnetites from Ruossakero, Lomalampi, and Vaara and Kovero non-mineralized samples occur mostly outside of this field. Magnetites from non-mineralized altered cumulate from Vaara are located in both the $\mathrm{Ni}-\mathrm{Cu}$ and layered intrusion fields and magnetites from magnetite veins from Lomalampi plot in both the $\mathrm{Ni}-\mathrm{Cu}$ field and anorthosite field. In general, because of alteration, our data show a large scatter in these discrimination diagrams, and therefore, the magnetite compositions cannot necessarily be used to discriminate their origin but rather give information on the changes in the composition of iron oxides during alteration.

Mineral inclusions in magnetite grains could also provide information on phases which crystallized before, or together with, magnetite. We found that some magnetites in the mineralized samples host base metal sulfide inclusions (Fig. 4). This indicates that the oxide phase is segregated and crystallized at the same time or later than the sulfide phase. From the mineral exploration point of view, this is a good indication of sulfide formation, especially if there is magnetite with $\mathrm{Ni}$ bearing sulfide or platinum-group metal (PGM) inclusions.
Studying indicator minerals from till is a useful and widely used exploration tool in glaciated terrains, indicating a potential existence of occurrences of mineral deposits, such as those of diamond, gold, and various base and precious metals (e.g., Sarala 2015 and references therein). Till geochemistry and indicator-mineral signatures have also been utilized in exploration for magmatic $\mathrm{Ni}-\mathrm{Cu}-\mathrm{PGE}$ deposits, especially in Canada (e.g., McClenaghan et al. 2011 and references therein). Ward et al. (2018) successfully used magnetite as a geochemical indicator for a Ni-Cu-PGE deposit in the Munali area, Zambia by sampling and analyzing soil overburden samples. A methodology of extracting magnetite grains from till samples, analyzing their composition with EPMA and LAICP-MS, applying selected discrimination diagrams to the resulting data, and studying mineral inclusions within the grains could be developed into a sound exploration strategy for discovering new magmatic $\mathrm{Ni}-\mathrm{Cu}$ deposits. Nevertheless, it is important to note that the magnetite compositions from barren rocks and alteration effects on magnetite composition have yet to be studied in sufficient detail, and in the future, a more comprehensive data set of magnetite compositions from a wider range of rock types, including barren rocks, could improve the quality of the discrimination diagrams. Because of this, magnetite compositions as a Ni sulfide exploration tool for samples that are highly altered by post-magmatic processes should be applied with caution.

\section{Conclusions}

1) Our results indicate that the trace element concentrations in oxide phases vary from two to three orders of magnitude, reflecting both the silicate (e.g., magnetites in the massive sulfide sample from Pechenga have high $\mathrm{Ti}, \mathrm{Nb}$, and $\mathrm{Ta}$ ) and sulfide melt compositions from which they have crystallized, and post-magmatic modification processes (magnetites in the Vaara deposit, which were formed from post-magmatic oxidation of sulfides are high in $\mathrm{Ni}, \mathrm{Cu}$, and $\mathrm{Pb}$ ).

2) The massive ore samples from Pechenga contain an oxide phase varying in composition from $\mathrm{Cr}$-magnetite to magnetite, indicating that $\mathrm{Cr}$-magnetite can crystallize directly from sulfide liquid.

3) The Ni concentration of magnetite is a function of the average Ni tenor of the sulfide phase with which magnetite is associated, regardless of whether the sulfide phase is magmatic or post-magmatic in origin. This indicates that a high Ni concentration of magnetite could be a primary feature, which is related to a high Ni content of sulfide or silicate liquid from which these $\mathrm{Fe}$ oxides 
crystallized, or it can reflect to post-magmatic oxidation of sulfides, and formation of secondary magnetite.

4) The $\mathrm{Mg}$ concentration of magnetite in massive ore samples (Pechenga and Hietaharju) is clearly lowest among the analyzed samples and can be regarded as a diagnostic feature of an oxide phase crystallized together with primitive Fe-rich MSS in a microenvironment more or less isolated from associated silicate magma.

5) Results indicate that the magnetite composition (e.g., high $\mathrm{Ni}$ and relatively low $\mathrm{Mg}$ and high Ga in magnetites from massive sulfide) together with petrographical observations (especially Ni-bearing sulfide inclusions inside magnetite) could be potentially used as an exploration tool for new Ni-Cu-PGE deposits in glaciated terrains, including Fennoscandia.

Acknowledgments Open access funding provided by University of Oulu including Oulu University Hospital. This research was supported by the Academy of Finland (grant \#281859), K.H. Renlund Foundation and Tauno Tönning Foundation. We thank Leena Palmu for guidance with electron microprobe analysis. Two anonymous reviewers are acknowledged for their helpful comments, which significantly improved the manuscript. We are grateful to Bernd Lehmann and Pasi Eilu for their useful comments and editorial work.

Open Access This article is licensed under a Creative Commons Attribution 4.0 International License, which permits use, sharing, adaptation, distribution and reproduction in any medium or format, as long as you give appropriate credit to the original author(s) and the source, provide a link to the Creative Commons licence, and indicate if changes were made. The images or other third party material in this article are included in the article's Creative Commons licence, unless indicated otherwise in a credit line to the material. If material is not included in the article's Creative Commons licence and your intended use is not permitted by statutory regulation or exceeds the permitted use, you will need to obtain permission directly from the copyright holder. To view a copy of this licence, visit http://creativecommons.org/licenses/by/4.0/.

\section{References}

Barnes SJ (2000) Chromite in komatiites, II. Modification during greenschist to mid-amphibolite facies metamorphism. J Petrol 41: 387-409. https://doi.org/10.1093/petrology/41.3.387

Barnes S-J, Roeder PL (2001) The range of spinel compositions in terrestrial mafic and ultramafic rocks. J Petrol 42:2279-2302. https:// doi.org/10.1093/petrology/42.12.2279

Boutroy E, Dare SAS, Beaudoin G, Barnes S-J, Lightfoot PC (2014) Magnetite composition in Ni-cu-PGE deposits worldwide: application to mineral exploration. J Geochem Explor 145:64-81. https:// doi.org/10.1016/j.gexplo.2014.05.010

Chai G, Naldrett AJ (1992) The Jinchuan ultramafic intrusion: cumulate of a high-MgO basaltic magma. J Petrol 33:277-303. https://doi.org/ 10.1093/petrology/33.2.277
Dare SAS, Barnes S-J, Beaudoin G (2012) Variation in trace element content of magnetite crystallized from a fractionating sulfide liquid, Sudbury, Canada: implications for provenance discrimination. Geochim Cosmochim Acta 88:27-50. https://doi.org/10.1016/j. gca.2012.04.032

Dare SAS, Barnes S-J, Beaudoin G, Méric J, Boutroy E, Potvin-Doucet C (2014) Trace elements in magnetite as petrogenetic indicators. Mineral Deposita 49:785-796. https://doi.org/10.1007/s00126014-0529-0

DigiKP (2018) Bedrock of Finland 1:200 000 - digital map database [dataset]. Espoo, Geological Survey of Finland (accessed 25 August 2018) https:/hakku.gtk.fi/en/locations/search

Djon ML, Peck DC, Olivo GR, Miller JD, Joy B (2018) Contrasting styles of Pd-rich magmatic sulfide mineralization in the Lac des Iles Intrusive Complex, Ontario, Canada. Econ Geol 113:741-767. https://doi.org/10.5382/econgeo.2018.4568

Dupuis C, Beaudoin G (2011) Discriminant diagrams for iron oxide trace element fingerprinting of mineral deposit types. Mineral Deposita 46:319-335

Duran CJ, Barnes S-J, Corkery JT (2016) Trace element distribution in primary sulfides and $\mathrm{Fe}-\mathrm{Ti}$ oxides from the sulfide-rich pods of the Lac des Iles Pd deposits, Western Ontario, Canada: Constraints on processes controlling the composition of the ore and the use of pentlandite compositions in exploration. J Geochem Explor 166: 45-63. https://doi.org/10.1016/j.gexplo.2016.04.005

Ewers WE, Graham J, Hudson DR, Rolls JM (1976) Crystallization of chromite from nickel-iron sulfide melts. Contrib Mineral Petrol 54: $61-64$

Fonseca ROC, Campbell IH, O'Neill HSC, Fitzgerald J (2008) Oxygen solubility and speciation in sulfide-rich mattes. Geochim Cosmochim Acta 72:2619-2635. https://doi.org/10.1016/j.gca. 2008.03.009

Frost KM, Groves DI (1989) Magmatic contacts between immiscible sulfide and komatiite melts: implications for the genesis of Kambalda sulfide ores. Econ Geol 84:1697-1704. https://doi.org/ 10.2113/gsecongeo.84.6.1697

Guillong M, Hametner K, Reusser E, Wilson SA, Günther D (2005) Preliminary characterisation of new glass reference materials (GSA-1G, GSC-1G, GSD-1G and GSE-1G) by laser ablationinductively coupled plasma mass spectrometry using $193 \mathrm{~nm}$, $213 \mathrm{~nm}$ and $266 \mathrm{~nm}$ wavelengths. Geostand Geoanal Res 29:315331. https://doi.org/10.1111/j.1751-908X.2005.tb00903.x

Hanski EJ (1992) Petrology of the Pechenga ferropicrites and cogenetic, Ni-bearing gabbro-wehrlite intrusions, Kola Peninsula, Russia. Geol Surv Finland, Bull 367

Hanski EJ, Huhma H (2005) Central Lapland greenstone belt. In: Lehtinen M, Nurmi PA, Rämö OT (eds) Precambrian geology of Finland - key to the evolution of the Fennoscandian shield. Elsevier B.V., Amsterdam, pp 139-193. DOI: https://doi.org/10.1016/ S0166-2635(05)80005-2

Hanski EJ, Smolkin VF (1995) Iron- and LREE-enriched mantle source for early Proterozoic intraplate magmatism as exemplified by the Pechenga ferropicrites, Kola Peninsula, Russia. Lithos 34:107125. https://doi.org/10.1016/0024-4937(95)90015-2

Hanski EJ, Huhma H, Rastas P, Kamenetsky VS (2001) The Paleoproterotzoic komatiite-picrite association of Finnish Lapland. J Petrol 42:855-876. https://doi.org/10.1093/petrology/42.5.855

Hanski EJ, Luo Z-Y, Oduro H, Walker RJ (2011) The Pechenga Ni-Cu sulfide deposits, northwestern Russia: a review with new constraints from the feeder dikes. Rev Econ Geol 17:145-162

Heikura P, Törmänen T, Iljina M, Salmirinne H (2009) Report on nickel and PGE exploration in the area of the claims Tulppionkariste 1-5 
(claim nos. 8246/1-5), Sodankylä municipality, during 2005-2008. Geol Surv Finl, Rep M06/4723/2009/68 (in Finnish)

Huhma H, Mänttäri I, Peltonen P, Kontinen A, Halkoaho T, Hanski E, Hokkanen T, Hölttä P, Juopperi H, Konnunaho J, Lahaye Y, Luukkonen E, Pietikäinen K, Pulkkinen A, Sorjonen-Ward P, Vaasjoki M, Whitehouse M (2012). The age of the Archaean greenstone belts in Finland. In: Hölttä P (ed) The Archaean of the Karelia Province in Finland. Geol Surv Finland Spec Pap 54:74-175

Jochum KP, Willbold M, Raczeck I, Stoll B, Herwig K (2005) Chemical characterisation of the USGS reference glasses GSA-1G, GCS-1G, GSD-1G, GSE-1G, BCR-2G, BHVO-2G and BIR-1G using EPMA, ID-TIMS, ID-ICP-MS and LA-ICP-MS. Geostand Geoanal Res 29:285-302. https://doi.org/10.1111/j.1751-908X. 2005.tb00901.x

Juopperi H, Vaasjoki M (2001) U-Pb mineral age determinations from Archean rocks in eastern Lapland. In: Vaasjoki M (ed) radiometric age determinations from Finnish Lapland and their bearing on the timing of Precambrian volcano-sedimentary sequences. Geol Surv Finland Spec Pap 33:209-227

Karinen T, Lepistö S, Konnunaho JP, Laura SL, Manninen T, Huhma H (2015) Unit description report Enontekiö, Käsivarsi. Geol Surv Finl, Rep 66/2015 (In Finnish)

Konnunaho J (1999) Komatiites and their ore potential in the Archean Kovero greenstone belt. MSc thesis, University of Oulu (in Finnish)

Konnunaho JP (2016) Komatiite-hosted Ni-Cu-PGE deposits in Finland: Their characterization, $\mathrm{PGE}-$ contents, and petrogenesis. $\mathrm{PhD}$ thesis, Geological Survey of Finland, Espoo

Konnunaho J, Hanski EH, Bekker A, Halkoaho TAA, Hiebert RS, Wing BA (2013) The Archean komatiite-hosted, PGE-bearing Ni-Cu sulfide deposit at Vaara, eastern Finland: evidence for assimilation of external sulfur and post-depositional desulfurization. Mineral Deposita 48:967-989

Konnunaho J, Halkoaho T, Hanski E, Törmänen T (2015) Komatiitehosted Ni-Cu-PGE deposits of the Finland. In: Maier W, O'Brien H, Lahtinen R (eds) Mineral deposits of Finland. Elsevier, Amsterdam, pp 93-128. https://doi.org/10.1016/B978-0-12410438-9.00004-2

Konnunaho JP, Hanski E, Wing B, Bekker A, Lukkari S, Halkoaho T (2016) The Hietaharju PGE-enriched komatiite-hosted sulfide deposit in the Archean Suomussalmi greenstone belt, eastern Finland. Ore Geol Rev 72:641-658. https://doi.org/10.1016/j.oregeorev. 2015.08.022

Lahtinen R, Korja A, Nironen M (2005) Paleoproterozoic tectonic evolution. In: Lehtinen M, Nurmi PA, Rämö OT. (eds) Precambrian Geology of Finland - Key to the Evolution of the Fennoscandian Shield. Elsevier B.V., Amsterdam, pp. 481-531

Lee WP (1999) The thermodynamic behavior of magnetite in non-ferrous smelting. PhD thesis, Graduate Department of Metallurgy and Materials Science, University of Toronto

Lehtonen M, Airo ML, Eilu P, Hanski E, Kortelainen V, Lanne E, Manninen T, Rastas P, Räsänen J, Virransalo P (1998) The stratigraphy, petrology and geochemistry of the Kittilä greenstone area, northern Finland: A report of the Lapland Volcanite Project. Geol Surv Finl, Rep. Invest. 140. (in Finnish with English summary)

Liu P-P, Zhou M-F, Chen WT, Gao J-F, Huang X-W (2015) In-situ LAICP-MS trace elemental analyses of magnetite: Fe-Ti-(V) oxidebearing mafic-ultramafic layered intrusions of the Emeishan Large Igneous Province, SW China. Ore Geol Rev 65:853-871. https:// doi.org/10.1016/j.oregeorev.2014.09.002

Locmelis M, Fiorentini ML, Barnes SJ, Hanski E, Kobussen AF (2018) Ruthenium in chromite as an indicator for the magmatic sulfide ore potential of mafic-ultramafic systems. Ore Geol Rev 97:152-170. https://doi.org/10.1016/j.oregeorev.2018.05.002

Luolavirta K, Hanski E, Maier W, Santaguida F (2017) Whole-rock and mineral compositional constraints on the magmatic evolution of the $\mathrm{Ni}-\mathrm{Cu}$-(PGE) sulfide ore-bearing Kevitsa intrusion, northern Finland. Lithos 296-299:37-53. https://doi.org/10.1016/j.lithos. 2017.10.015

Luukas J, Kousa J, Nironen M, Vuollo J (2017) Major stratigraphic units in the bedrock of Finland, and an approach to tectonostratigraphic division. Metamorphism and tectonic evolution. Geol Surv Finland Spec Pap 60:9-39

Luukkonen E, Halkoaho T, Hartikainen A, Heino T, Niskanen M, Pietikäinen K, Tenhola M (2002) Report of activities in 19922001 of the project Archean Areas in Eastern Finland (12201 ja 210 5000) in the areas of Suomussalmi, Hyrynsalmi, Kuhmo, Nurmes, Rautavaara, Valtimo, Lieksa, Ilomantsi, Kiihtelysvaara, Eno, Kontiolahti, Tohmajärvi and Tuupovaara. Geol Surv Finl, Rep M19/4513/2002/1 (in Finnish)

Maier WD, Peltonen P, Halkoaho T, Hanski E (2013) Geochemistry of komatiites from the Tipasjärvi, Kuhmo, Suomussalmi, Ilomantsi and Tulppio greenstone belts, Finland: implications for tectonic setting and Ni sulfide prospectivity. Precambrian Res 228:63-84. https://doi.org/10.1016/j.precamres.2012.12.004

McClenaghan MB, Layton-Matthews D, Matile G (2011) Till geochemical signatures of magmatic Ni-cu deposits, Thompson Nickel Belt, Manitoba, Canada. Geochem: Expl, Environ, Anal 11:145-159. https://doi.org/10.1144/1467-7873/09-IAGS-021

Metamorphism of Finland 1:1000 000. Digital map database [dataset]. Espoo, Geological Survey of Finland (accessed 21 August 2018). https://hakku.gtk.fi/en/locations/search

Moilanen M, Hanski E, Konnunaho J, Yang SH, Törmänen T, Li C, Zhou LM (2019) Re-Os isotope geochemistry of komatiite-hosted Ni-CuPGE deposits in Finland. Ore Geol Rev 105:102-122. https://doi. org/10.1016/j.oregeorev.2018.12.007

Mutanen T (1997) Geology and ore petrology of the Akanvaara and Koitelainen mafic layered intrusions and the Keivitsa-Satovaara layered complex, Northern Finland Geol Surv Finl, Bull 395

Mutanen T, Huhma H (2001) U-Pb geochronology of the Koitelainen, Akanvaara and Keivitsa layered intrusions and related rocks. In: Vaasjoki M (eds) radiometric age determinations from Finnish Lapland and their bearing on the timing of Precambrian volcanosedimentary sequences. Geol Surv Finland Spec Pap 33:229-246

Nadoll P, Angerer T, Mauk JL, French D, Walshe J (2014) The chemistry of hydrothermal magnetite: a review. Ore Geol Rev 61:1-32. https:// doi.org/10.1016/j.oregeorev.2013.12.013

Naldrett AJ (2004) Magmatic sulfide deposits. Geology, geochemistry and exploration. Springer, Berlin

Osmond RT, Watts AH, Ravenhurst WR, Foley CP, Leslie KE (2002) Finding nickel from the B-field at Raglan - ' To B or not dB'. Recorder 27, No. 9. https://csegrecorder.com/articles/view/findingnickel-from-the-b-field-at-raglan

Papunen H (1989) Platinum-group elements in metamorphosed $\mathrm{Ni}-\mathrm{Cu}$ deposits in Finland. In: Prendergast MD, Jones MJ (eds) Magmatic sulfides - the Zimbabwe volume. The Institution of Mining and Metallurgy, London, pp 165-176

Papunen H, Halkoaho T, Luukkonen E (2009) Archean evolution of the Tipasjärvi-Kuhmo Suomussalmi Greenstone Complex, Finland. Geol Surv Finl, Bull 403

Pekkarinen L (1980) The Tainiovaara Ni deposit in Lieksa. Geologi 7:92 (in Finnish)

Rudnick R, Gao S (2003) Composition of the continental crust. In: Rudnick RL (ed) Treatise on geochemistry, volume 3. Elsevier, 
Amsterdam, pp 1-64. DOI: https://doi.org/10.1016/B0-08-0437516/03016-4

Santaguida F, Luolavirta K, Lappalainen M, Ylinen J, Voipio T, Jones S (2015) The Kevitsa Ni-Cu-PGE deposit in the Central Lapland greenstone belt in Finland. In: Maier W, Lahtinen R, O'Brien H (eds) Mineral deposits of Finland. Elsevier, Amsterdam, pp 195-210. https://doi.org/10.1016/ B978-0-12-410438-9.00008-X

Sarala P (2015) Surficial geochemical exploration methods. In: Maier W, Lahtinen R, O'Brien H (eds) Mineral deposits of Finland. Elsevier B.V, Amsterdam, pp 711-731. https://doi.org/10.1016/B978-0-12410438-9.00027-3

Sorjonen-Ward P, Luukkonen EJ (2005) Archean rocks. In: Lehtinen M, Nurmi PA, Rämö OT (eds) Precambrian geology of Finland - key to the evolution of the Fennoscandian Shield. Elsevier B.V, Amsterdam, pp 21-99. https://doi.org/10.1016/S0166-2635(05) 80003-9

Törmänen T, Konnunaho JP, Hanski E, Moilanen M, Heikura P (2016) The Paleoproterozoic komatiite-hosted PGE mineralization at Lomalampi, Central Lapland Greenstone Belt, northern Finland. Mineral Deposita 51:411-430

Van Achterbergh E, Ryan CG, Jackson SE, Griffin WL (2001) Data reduction software for LA-ICP-MS. in: Sylvester SP (ed) Laser-
ablation-ICPMS in the earth sciences: principles and applications. Miner Assoc Can, Short Course Series 29:239-243

Vanne J (1981) Report on exploration in the area of the claim Tainiovaara 1(claim no. 2538/1). Geol Surv Finl, Rep M 06/4332/81/1/10 (in Finnish)

Ward LA, Holwell DA, Barry TL, Blanks DE, Graham SD (2018) The use of magnetite as a geochemical indicator in the exploration for magmatic Ni-Cu-PGE sulfide deposits: a case study from Munali, Zambia. J Geochem Explor 188:172-184. https://doi.org/10.1016/j. gexplo.2018.01.018

Yang S-H, Maier WD, Hanski EJ, Lappalainen M, Santaguida F, Määttä S (2013) Origin of ultra-nickeliferous olivine in the Kevitsa Ni-cuPGE-mineralized intrusion, northern Finland. Contrib Mineral Petrol 166:81-95

Yang S-H, Yang G, Qu W, Du A, Hanski E, Lahaye Y, Chen J (2018) PtOs isotopic constraints on the age of hydrothermal overprinting on the Jinchuan Ni-Cu-PGE deposit, China. Mineral Deposita 53:757774

Publisher's note Springer Nature remains neutral with regard to jurisdictional claims in published maps and institutional affiliations. 